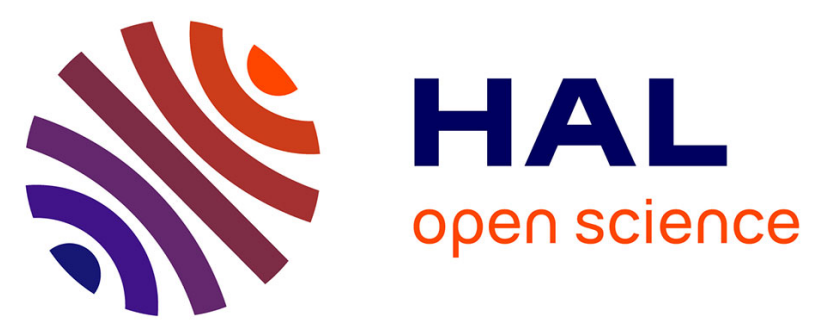

\title{
Pelagic food web patterns: do they modulate virus and nanoflagellate effects on picoplankton during the phytoplankton spring bloom?
}

\author{
Pascaline J Ory, Hans J Hartmann, Florence J Jude, Christine Dupuy, \\ Yolanda del Amo, Philippe Catala, Françoise Mornet, Valérie Huet, Jan J \\ Benoit, Dorothée Vincent, et al.
}

\section{To cite this version:}

Pascaline J Ory, Hans J Hartmann, Florence J Jude, Christine Dupuy, Yolanda del Amo, et al.. Pelagic food web patterns: do they modulate virus and nanoflagellate effects on picoplankton during the phytoplankton spring bloom?. Environmental Microbiology, 2010, 12 (10), pp.2755-2772. 10.1111/j.1462-2920.2010.02243.x . hal-01422545

\section{HAL Id: hal-01422545 https://hal.science/hal-01422545}

Submitted on 26 Dec 2016

HAL is a multi-disciplinary open access archive for the deposit and dissemination of scientific research documents, whether they are published or not. The documents may come from teaching and research institutions in France or abroad, or from public or private research centers.
L'archive ouverte pluridisciplinaire HAL, est destinée au dépôt et à la diffusion de documents scientifiques de niveau recherche, publiés ou non, émanant des établissements d'enseignement et de recherche français ou étrangers, des laboratoires publics ou privés. 
Pelagic food web patterns: do they modulate virus and nanoflagellate effects on picoplankton during the phytoplankton spring bloom?

6

1 Littoral, Environnement et SociétéS (LIENSS) Université de La Rochelle UMR 6250 CNRS-ULR, 2 rue Olympe de Gouges, 17042 La Rochelle Cedex, France

2 Environnements et Paleoenvironnement Océaniques (EPOC) Université de Bordeaux 1 UMR 5805 CNRS, 2 rue du Professeur Jolyet, 33120 Arcachon, France

3 Observatoire Océanologique de Banyuls-sur-Mer UMR 7621 CNRS-Université Pierre et Marie Curie, Avenue Fontaulé, 66650 Banyuls-sur-Mer, France

4 UMS 3109 CNRS-IFREMER Environnement Littoral Atlantique, Place du Séminaire, 17137 L'Houmeau, France

5 Laboratoire d'Océanologie et de Geosciences (LOG) Université du Littoral Coté d'Opale UMR CNRS 8187, 32 avenue Foch, 62930 Wimereux, France

*Corresponding author: Tel +335 46458314 E-mail address: pory01@univ-lr.fr

$\uparrow$ These authors contributed equally to this work

\section{Running title:}




\section{Summary}

28 As agents of mortality, viruses and nanoflagellates impact on picoplankton populations. We examined the differences in interactions between these compartments in two French Atlantic bays.

30 Microbes, considered here as central actors of the planktonic food web, were first monitored seasonally in Arcachon (2005) and Marennes-Oléron (2006) bays. Their dynamics were evaluated to categorize trophic periods using the models of Legendre and Rassoulzadegan (1995) as a reference framework. Microbial interactions were then compared through 48h-batch-culture experiments performed during the phytoplankton spring bloom, identified as herbivorous in Marennes and multivorous in Arcachon. Marennes was spatially homogeneous compared to Arcachon. The former was potentially more productive, featuring a large number of heterotrophic pathways, while autotrophic mechanisms dominated in Arcachon. A link was found between viruses and phytoplankton in Marennes, suggesting a role of virus in the regulation of autotroph biomass. Moreover, the virus-bacteria relation was weaker in Marennes, with a bacterial lysis potential of $2.6 \%$ compared with $39 \%$ in Arcachon. The batch experiments (based on sizefractionation and viral enrichment) revealed different microbial interactions that corresponded to the spring-bloom trophic interactions in each bay. In Arcachon, where there is a multivorous web, flagellate predation and viral lysis acted in an opposite way on picophytoplankton. When together they both reduced viral production. Conversely, in Marennes (herbivorous web), flagellates and viruses together increased viral production. Differences in the composition of the bacterial community composition explained the combined flagellate-virus effects on viral production in the two bays.

\section{Introduction}

50 The long held paradigm that primary production is transferred through a herbivorous chain to small

51 and large phytovores neglects the importance of most microorganisms. Yet bacteria, which are 52 present at up to $10^{6}$ cells. $\mathrm{ml}^{-1}$, and viruses, whose concentration can reach $10^{8}$ viral particles.ml ${ }^{-1}$, 
dominate in the oceans (Borsheim et al., 1990; Hennes and Suttle, 1995; Li, 1998). Bacteria were primarily considered as remineralizers providing inorganic nutrients for primary producers. Later, the microbial loop concept (Azam et al., 1983) highlighted the role of bacteria as recyclers of DOM originating either from primary production or from losses at different trophic levels. Thus, the role of bacteria in the microbial loop evolved from that of a matter sink to a trophic link towards bacterivorous organisms. Moreover, bacterial community dynamics are not only controlled by resources i.e. bottom-up control, such as the availability of inorganic nutrients and the quality of DOM (Kirchman et al., 2000), but also by predation i.e. top-down control, examples being the mortality induced by protists such as nanoflagellates and ciliates and by viral lysis. (Sanders et al., 1992; Fuhrman, 1999). The selectivity of protist predation based on size, motility, shape and cell surface properties of prey (Gonzalez et al., 1990; Monger et al., 1999) can potentially impact on the morphological characteristics of bacteria and shape their community composition (BCC) (Hahn and Hofle, 2001; Posch et al., 2001). On an ecosystem level, protist predation may exert a stronger control in oligotrophic waters than in eutrophic waters (Gasol et al., 2002).

Since the 1990's, viruses have been considered as an additional factor in the mortality of bacteria (Fuhrman, 1999), other micro-organisms such as microalgae (Cottrell and Suttle, 1995) and unpigmented flagellates (Garza and Suttle, 1995; Massana et al., 2007). Virus-mediated bacterial mortality could account for $48-84 \%$ of bacterial production in oligotrophic areas and $59 \%$ in eutrophic areas (Boras et al., 2009). Regarding the biogeochemical aspects of the ecosystem, viral lysis shunts carbon flow (Fuhrman, 1999): 6 to $26 \%$ of photosynthetically fixed carbon flows back to DOM, becoming available for microbial uptake and consequently modifying the competitive balance of phytoplankton and bacteria for limiting nutrients (Wilhelm and Suttle, 1999). Moreover, viral infection could potentially maintain the species richness of bacteria, as described in the "kill the winner" concept (Thingstad and Lignell, 1997). The density dependence of viral infection could limit dominant and competitive bacteria and give an advantage to less competitive ones (Bouvier and Del Giorgio, 2007; Weinbauer et al., 2007; Auguet et al., 2009), although this idea is still 
controversial (Winter et al., 2004). In addition, host specificity could concern strains instead of species because of the phenotype plasticity of the viral permissivity-resistance characters (Schwalbach et al., 2004; Fuhrman, 2009).

Even if virioplankton is mainly composed of bacteriophages (Fuhrman, 1999; Suttle, 2005), a link with phytoplankton or chlorophyll a concentrations, suggesting phytophage pathogenicity (Wommack and Colwell, 2000), has already been underlined in some long term surveys where there were high densities of algal cells (Maranger et al., 1994) as well as in offshore stations (Boehme et al., 1993; Guixa-Boixereu et al., 1999) or in coastal regions at the deep chlorophyll $a$ maximum (Baudoux et al., 2008). Organisms less than $3 \mu \mathrm{m}$ in size may be responsible of large part of primary production, in particular in oligotrophic areas (Platt et al., 1983). Autotrophic as well as heterotrophic pico- and nanoplankton are too small to be efficiently consumed by metazoans (Sherr and Sherr, 1988); they are mainly consumed by flagellates and ciliates (Sherr and Sherr, 1994) and can significantly contribute to their diet (Hirose et al., 2008). However, the grazing yield from phytoplankton is lower than from bacteria. Furthermore, predation on protists indirectly affects bacterial grazing, enhancing viral impact (Boras et al., 2009). Thus, as the preferential prey of copepods (Nielsen and Kiorboe, 1994), ciliates can be considered as a trophic link between picoand nano-plankton and mesozooplankton (superior trophic levels) (Calbet and Saiz, 2005).

To assess the importance of microbiological plankton compartments in matter flow, Legendre and Rassoulzadegan (1995) described 4 major trophic concepts each incorporating different dominant carbon pathways: (1) The herbivorous or classical food web, which is based on large-phytoplankton $(>5 \mu \mathrm{m})$ primary production leading to large zooplankton organisms. (2) The microbial food web, in which primary production is mainly due to small phytoplankton and comprises pathways involving heterotrophic bacteria and protozoa. (3) The microbial loop, a nearly closed system where carbon flows are limited to heterotrophic bacteria and unpigmented protists; DOM released by the grazers becomes substrate for bacteria. (4) Finally, the multivorous food web, a transitional trophic system 
comprising diverse heterotrophic carbon pathways in which both large and small phytoplankters are significant primary producers.

Accordingly, the question arises: do the interactions between microbial compartments (in particular between viruses, picoplankton and nanoflagellates) vary depending on the trophic pathway? So far, despite the clear importance of heterotrophic microorganisms in pelagic food webs, descriptions of trophic models have mostly been based on primary producer size, water column stratification and nutrients (Rivkin et al., 1996; Marquis et al., 2007). Thus, to answer this question, two sites along the French Atlantic coast that are distinctive in terms of their river inputs and hydrology (shape, mixing regime and water residence time) were chosen as study case areas to describe the temporal succession of trophic pathways. The temporal dynamics of abiotic parameters and microbiological compartments were assessed over 7 months in Arcachon Bay in 2005 and over one year in Marennes Oléron Bay in 2006. Located North-Southward along the coast of the Bay of Biscay, Arcachon and Marennes-Oléron Bays are both semi-enclosed and macrotidal lagoons, largely composed of intertidal mudflats (Blanchet et al., 2008; Allard et al., 2009). Like many estuaries and bays, the 2 basins are highly productive, featuring a large-phytoplankton spring bloom (Struski and Bacher, 2006; Glé et al., 2008). In this context, does the large-phytoplankton spring bloom entail similar trophic pathways in each bay and thus similar interactions between the above-mentioned microbial compartments? To answer this question, we first defined the trophic succession for each bay, then located the spring phytoplankton bloom within this succession, and finally in vitro experiments were performed during this period to analyse the quantitative and qualitative impact of nanoflagellate grazing and viral lysis on picoplankton. 


\section{Results}

\section{IN SITU SURVEYS}

\section{Environmental context}

133 The evolution of the abiotic parameters in the 2 bays followed a typical temperate-coastal pattern 134 featuring peak temperatures and salinities in the summer together with low nutrient levels during 135 the period of low runoff. On average, Arcachon Bay (Arc) had fewer nutrients than Marennes (M-O) 136 (Table S1 and S2). Arc waters were spatially heterogeneous, with significant differences of salinity, 137 temperature and most nutrients between the 2 stations (ANOVA, $\mathrm{H}_{0}$ no difference between stations 138 is rejected, $\mathrm{p}<0.05$ ). By contrast, $\mathrm{M}-\mathrm{O}$ was homogeneous over 4 of the 5 stations (ANOVA p>0.05). 139 The Charente station differed from the four others, with higher nutrient levels and lower salinity 140 (ANOVA with Tukey multiple comparisons, $\mathrm{p}>0.05$ ) (Table S1).

\section{Zonation and seasonality of microbial distribution}

143 The bacteria/virus relationship $\left(r^{2} \geq 0.6\right)$ in Arc was stronger than in M-O. However, the response of 144 bacteria to increasing viruses was weaker in Arc $(\log / \log$ regression slopes $\leq 0.6)$ than in $\mathrm{M}-\mathrm{O}$ 145 (slopes $\geq 0.84$, Table 1). In Arc, bacterial (BA) and viral (VA) abundances in Comprian were 146 significantly higher than in B13 (ANOVA, $\mathrm{p}<0.0002$, Table 1). In M-O, the BA/VA relationship 147 was equal in 4 of the 5 stations (Slope comparison, ANCOVA, p<0.05, n=96), but the relationship 148 was insignificant at Charente station $(\mathrm{p}=0.09)$ (Table 1). Nevertheless, no significant differences in 149 the annual abundance of viruses and bacteria were found between the 5 stations (ANOVA, $\mathrm{p}<0.05$ ). 150 Consequently, the global monthly and annual means (BA: $4.11 \pm 0.34 \times 10^{6}$ cells.ml $^{-1}$ and VA: $1513.38 \pm 0.34 \times 10^{7}$ particles. $\mathrm{ml}^{-1}$ ) are representative for the whole basin. The VBR (virus to bacteria 152 ratio) was higher in $\mathrm{M}-\mathrm{O}$ (annual mean= $11.16 \pm 5.39)$ compared to Arc $(4.06 \pm 1.17$ and $4.89 \pm$ 1531.96 at B13 and Comprian, respectively). In M-O, VBR tended to be higher from November to 154 April (>10) and lower during summer $(<10)$, while no trend was visible in Arc (data not shown). 
155 The results of PCA and HAC were analysed to compare the spatial and temporal organization of the 1562 bays (Fig. 1). Only samples from January to August were taken into account. Nutrients (23\%) and 157 viruses (7.5\%) contributed positively to axis 1 while Cryptophyceae (10\%), salinity (5\%), diatoms $158(5 \%)$ and Synechococcus (5\%) contributed negatively. Small phytoeukaryotes (16\%), temperature $159(14 \%)$, bacteria $(12.5 \%)$ and ciliates $(12.5 \%)$ contributed positively to axis 2 . The 2 axes accounted 160 for $52.67 \%$ of the total variance among the samples. Along the first axis, Arc was distinguished 161 from M-O by low nutrients (Table S1), a high abundance of autotrophs [Diatoms (mean: $1623.52 \pm 4.17 \times 10^{5}$ cell. $^{-1}$ vs. $0.65 \pm 1.45 \times 10^{5}$ cell. $^{-1}$ ), Cyanobacteria (mean: $1.77 \pm 2.83 \times 10^{4}$ vs. $1633.9 \pm 2.9 \times 10^{3}$ cell. $\left.\mathrm{ml}^{-1}\right)$, Cryptophyceae $\left(6.46 \pm 5.17 \times 10^{4}\right.$ vs. $13 \pm 28$ cell..$\left.\left.^{-1}\right)\right]$, as well as low VA $164\left(5.71 \pm 5.23 \times 10^{6}\right.$ vs. $3.37 \pm 1.21 \times 10^{7}$ particles. $\left.\mathrm{ml}^{-1}\right)$. Seasonal clusters were found along the second 165 axis for both basins (“winter": January - April and "summer": May - August), principally due to 166 higher summer temperatures combined with a higher abundance of microorganism in Arc (bacteria, 167 ciliates and pico- nanophytoplankton). Furthermore, a spatial subdivision appeared in Arc along 168 axis 1, distinguishing the inner (Comprian) from the outer (B13) sampling station. By contrast, the 169 M-O stations were homogeneous, although the Charente station points were always shifted to the 170 right because of a lower salinity and a higher level of nutrients. Moreover, the Charente station was 171 also distinguished by large amounts of suspended matter (Table S1).

172 Based on the results of this multivariate assessment, the basin dynamics were further distinguished 173 using the inner station of Arc (Comprian) and averages of the five M-O stations (because of their 174 spatial homogeneity) using multiple regressions. VA and BA dynamics can be related to the more 175 complex relationships in M-O compared to Arc (Table 2). The opposite was observed for 176 heterotrophic nanoflagellates. There are several important details: (i) in winter, BA was positively 177 related to viruses in both bays and to HNF in M-O but negatively in Arc. In summer, only the link 178 with viruses remained along with supplementary links with nutrients (ammonium, nitrite and 179 phosphate); (ii) there was a negative relationship between viruses and picophytoplankton all year 180 long in both bays as well as with HNF in Arc during the summer; viruses were positively linked to 
181 chla all year round in M-O but not in Arc. (iii) HNF were negatively related to ciliates during winter

182 (Table 2).

183

\section{Temporal succession of trophic pathways}

Herbivorous food webs were identified for $20 \%$ of the sampling period in Arc (February and August) and for $27 \%$ of the period in M-O (May and July-August, Fig. 2A,B). Multivorous webs were present for $21 \%$ of the period in Arc (May and the second half of August) and for 25\% of the period in M-O (3 weeks in February-March and 2 months between mid-October and midDecember). The microbial food web represented about half of the sampling period in both bays, yet they were not synchronized, except during March-April (Fig. 2). Finally, the microbial loop was absent in Arc, while it was present for 5\% of the period in M-O (two weeks at the end of March and one in September). During these two periods, bacteria grew 2.0x and 2.4x, viruses 2.0x and 2.0x, nanoflagellates 6.7x and 1.5x and ciliates 0 and 20x, respectively (Fig. 2B, "Microbial loop").

BA and VA evolved in parallel during all the trophic periods in Arc. However, the synchronisation was less obvious in M-O, particularly during the herbivorous and multivorous phases when VA did not decrease as much $(-1.6 \mathrm{x})$ as BA $(-2.1 \mathrm{x})$.

In Arc, the small phytoplankton (annual mean $=3.4 \pm 1.5 \times 10^{4}$ cells. $\mathrm{ml}^{-1}$ ) were dominated by picoplankton, with 3 major growth periods (early April, early May accompanied by nanoplankton, and from mid-June to end of July, also accompanied by nanoplankton). Large-phytoplankton, with an annual mean of $4.73 \pm 4.16 \times 10^{5}$ cells. $1^{-1}$, dominated at the beginning of the year, with mainly dinophyceae and cryptophyceae species; this was followed later by two diatom peaks (mid-May and late August). Three periods of growth of small phytoplankton were observed in M-O (annual mean $=1.98 \pm 1.71 \times 10^{4}$ cell. $\mathrm{ml}^{-1}$ ) that were mostly due to picoplankton (end of April, $4.9 \times 10^{4}$ cells. $\mathrm{ml}^{-1}$, early June, $6.8 \times 10^{4}$ cells.ml ${ }^{-1}$ and early July, $4 \times 10^{4}$ cells.ml ${ }^{-1}$ ). Large-phytoplankton (annual mean=7.05 $\pm 14.6 \times 10^{4}$ cells..$^{-1}$ ) developed at the end of March (mainly diatoms), early May (mainly diatoms) and early July (diatoms and dinoflagellates). Moreover, picophytoplankton and large 
phytoplankton accounted for the viral dynamics during the herbivorous and multivorous periods in

$208 \mathrm{M}-\mathrm{O}$ (simple regression, $\mathrm{p}=0.01$ and $\mathrm{p}=0.006$, respectively).

209 Nanoflagellate numbers increased systematically during the microbial phases in both Arc and M-O

210 at the beginning of the herbivorous and multivorous periods, just before the large-phytoplankton

211 blooms. Small cells dominated in the latter (annual mean: 88.2 $46.9 \%<3 \mu \mathrm{m}$ cells, Fig. 2). In Arc,

212 the pigmented/unpigmented ratio of nanoflagellates was higher (mean=11.6 vs. 3.9 in M-O).

213 Ciliate dynamics followed those of bacteria in $\mathrm{M}-\mathrm{O}$ except in mid-February (Fig. 2B).

214 Heterotrophic species dominated (annual mean of Strombidium spp plus Strobilidium spp: 55\% and

$21548 \%$ of the total abundance, respectively). The only exception was during the spring phytoplankton

216 bloom when autotrophic and potentially autotrophic taxa (Myrionecta rubra, Tontonia spp, Laboea $217 s p$ ) represented $60 \%$ and $80 \%$ of the total abundance. In Arc, ciliate dynamics followed those of 218 nanoflagellates, increasing during the microbial food web periods.

219 Finally, beyond the fact that the changes in the trophic pathways in the two bays are not 220 synchronized, the major difference was the contrasting organization at the beginning of the year, 221 which was herbivorous in Arc and microbial in M-O. Moreover, during the large-phytoplankton 222 spring blooms, M-O featured a herbivorous web pathway while Arc was in a multivorous phase.

\section{IN VITRO EXPERIMENTS}

225 Experiments were performed with water from Arcachon-Comprian $\left(2006 ; \mathrm{T}^{\circ}\right.$ in situ $=18.6^{\circ} \mathrm{C} ; \mathrm{S}=32$ PSU) and the Marennes-Station E (2007; $\mathrm{T}^{\circ}$ in situ $\left.=15^{\circ} \mathrm{C} ; \mathrm{S}=32.5 \mathrm{PSU}\right)$ collected at morning high tide. During incubation, the nighttime/daytime water temperature varied from $19.5^{\circ} \mathrm{C}$ to $23.3^{\circ} \mathrm{C}$ in 228 Arc and from $18^{\circ} \mathrm{C}$ to $22^{\circ} \mathrm{C}$ in $\mathrm{M}-\mathrm{O}$, respectively.

\section{Protists}

231 In Arc, the abundance of picophytoeukaryote (picoeuk) was equivalent in all treatments at the 232 beginning of the experiment $\left(1.8 \times 10^{3}\right.$ cells.ml $\left.{ }^{-1}\right)$. In the absence of predators, virus enrichment had a 
positive effect from $18 \mathrm{~h}$ to $38 \mathrm{~h}$, during which picoeuk abundance increased 18 -fold (Fig. 3A). But

234 in the presence of flagellates, picoeuk abundance dropped 4.5-fold. In M-O water, the abundance of 235 picoeuk was not significantly different between treatments despite an initial difference due to the 236 filtration step.

237 Pigmented nanoflagellates were few and varied little in both sites, (means: $6.4 \times 10^{4}$ cells..$^{-1}$ in Arc 238 and $9.6 \times 10^{4}$ cells..$^{-1}$ in M-O), making up $<1 \%$ and $<10 \%$ of the total nanoflagellates, respectively. 239 The nanoflagellates started growing at $18 \mathrm{~h}$ (Fig. 3E). Their growth rates were 2- to 4-fold higher in 240 Arc than in M-O (in $3 \mu-\operatorname{Tr}$ and $20 \mu$ - $\operatorname{Tr}$ respectively). Moreover, in both bays, the nanoflagellates in 241 the latter were significantly higher than in $3 \mu-\operatorname{Tr}(2$ way-ANOVA $\mathrm{p}<0.01)$ while the small cells $242(<3 \mu \mathrm{m})$ dominated and grew more rapidly than the large ones. During the $48 \mathrm{~h}$ incubations, the 243 small/large flagellate ratio increased from 5 to 100 in Arc and from 1.5 to 20 in M-O.

Bacterial abundance and growth rate

246 During the different treatments, bacterial abundance after $48 \mathrm{~h}$ increased 20-35 fold in Arc 247 (stationary phase) and 20-60 fold in M-O (logarithmic phase) (Fig. 3B). In Arc, the net bacterial 248 abundance increase (NBI) was always significantly greater in virus enriched treatments $(\mathrm{p}=0.005)$. 249 In M-O, the viral enrichment enhanced BA only in the $0.8 \mu \mathrm{m}$ treatments $(\mathrm{p}<0.05)$.

250 The maximum specific bacterial growth rate $(\mu \max )$ showed significant differences between 251 treatments: $\mu$ max was significantly higher in both bays with virus-enriched treatments compared to 252 the corresponding controls (2way ANOVA, p=0.02) (cf Fig. 3B black versus clear symbols). The 253 growth stimulation was 9-14\% in Arc and 12-33\% in M-O. However, the presence of flagellates did 254 not significantly modify $\mu$ max in either of the bays $(20 \mu \mathrm{m}$ and $3 \mu \mathrm{m}$ treatments versus $0.8 \mu \mathrm{m}$ 255 treatments; Fig. 3B)

256 In Arc, during the exponential phase, the growth rate of population 6 of HNA cells, which were the 257 most abundant, was stimulated in enriched- $0.8 \mu-\operatorname{Tr}(+44 \%)$ compared to the control, while 258 populations 3,4 and 5 were inhibited. The presence of flagellates ( $3 \mu$ and $20 \mu$ treatments) masked 
this particularity. In $\mathrm{M}-\mathrm{O}$, the growth rate of population 3 in the presence of flagellates was 260 significantly higher than those of the other populations (data not shown).

\section{Viral abundance and production}

263 The initial viral abundance was multiplied 2-3-fold in enriched-treatments in both Arc and M-O 264 (Fig. 3C). In Arc, some viruses were produced during the first 12 hours, except in $20 \mu$-Tr. A second, 265 stronger production phase was observed between 24 and $38 \mathrm{~h}$ in all treatments, persisting till the end 266 of the experiment in $3 \mu$-Tr. The presence of flagellates significantly decreased the total viral 267 production rate $(-50 \%$ in $3 \mu-\operatorname{Tr}$ and $-75 \%$ in $20 \mu-\operatorname{Tr})$ from $0.04 \mathrm{~h}^{-1}$ in $0.8 \mu-\operatorname{Tr}$ to $0.02 \mathrm{~h}^{-1}$ in $3 \mu-\operatorname{Tr}$ 268 and to $0.01 \mathrm{~h}^{-1}$ in $20 \mu-\operatorname{Tr}(2$ way-ANOVA, $\mathrm{p}=0.0002)$. Moreover, viral enrichment decreased the 269 viral production rate notably in presence of small predators $(-47.5 \%, \mathrm{p}=0.009)$ and in their absence, 270 yet not significantly $(-23 \% ; \mathrm{p}=0.1)$. In $\mathrm{M}-\mathrm{O}$, VA evolved differently with the various treatments: 271 viruses were produced between 12 and $18 \mathrm{~h}$ only in the presence of flagellates $(3 \mu$ - and $20 \mu$ 272 treatments). There was a second production phase from $38 \mathrm{~h}$ in all treatments except in the enriched$0.8 \mu-\operatorname{Tr}$ and $20 \mu-\operatorname{Tr}$. The net viral production over $48 \mathrm{~h}$ was negative $(-31 \%,-72 \%,-5.3 \%,-70 \%$ and $-65 \%$ in $0.8 \mu-\operatorname{Tr}$, enriched- $0.8 \mu-\operatorname{Tr}, 3 \mu-\operatorname{Tr}, 20 \mu-\operatorname{Tr}$ and enriched-20 $-\operatorname{Tr}$ respectively) except in

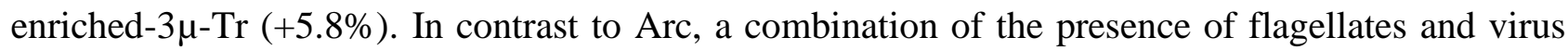
enrichment increased 2.5-fold the total viral production rate (from $0.01 \mathrm{~h}^{-1}$ in $0.8 \mu$-Tr to $0.025 \mathrm{~h}^{-1}$ in enriched-3 3 -Tr). The addition of viruses alone had the opposite effect (2way-ANOVA, interaction, $\mathrm{p}=0.006$ ), inducing a significant 6.5 -fold decrease (from $0.01 \mathrm{~h}^{-1}$ in $0.8 \mu$ - $\operatorname{Tr}$ to $0.0016 \mathrm{~h}^{-1}$ in enriched- $0.8 \mu-\operatorname{Tr})$.

\section{Virus mediated bacteriolysis}

282 In Arc, we calculated that $70 \pm 15 \%$ of the bacterial stock was lysed per day $(0.8 \mu-\operatorname{Tr})$. In the 283 presence of flagellates, this impact decreased significantly to $33.7 \pm 1.9 \%(3 \mu-\operatorname{Tr})$ and $39 \pm 11 \%(20 \mu-$ 284 Tr) (ANOVA: $\mathrm{p}=0.01)$. By contrast, virus mediated lysis was less severe in $\mathrm{M}-\mathrm{O}(13.6 \pm 1.7 \%$ of 
bacterial stock lysed per day without any predators). Small flagellates had no effect $(9.4 \pm 4.6 \%$ in $3 \mu-\operatorname{Tr}, p>0.05)$. However, in the presence of all the flagellates $(20 \mu-\operatorname{Tr})$, the percentage of lysed bacteria significantly decreased to $2.6 \pm 0.3 \%$ (ANOVA, $\mathrm{p}=0.009$ ).

\section{Bacterial enzymatic activity and community composition}

In Arc, the change in specific maximum velocity of potential aminopeptidase activity (specific Vmax) was similar in all treatments, with a peak at $24 \mathrm{~h}$. Specific activity dropped at $38 \mathrm{~h}$ except in $3 \mu-\operatorname{Tr}$, where a strong activity was maintained until the end of the experiment (Fig. 3D). There was a negative relationship between picoeuk abundance and bacterial proteolytic activity, which was significant only in the presence of flagellates (Simple regression: $\mathrm{r}^{2}=92 \% \mathrm{p}<0.0001 \mathrm{n}=15$ in $3 \mu-\mathrm{Tr}$, $\mathrm{r}^{2}=29 \% \mathrm{p}=0.022, \mathrm{n}=15$ in enriched $-3 \mu-\mathrm{Tr}$ ). The specific Vmax peaked also at $24 \mathrm{~h}$ in M-O, except in the enriched- $3 \mu-\operatorname{Tr}$ at $12 \mathrm{~h}$. In both bays, peaks of activity occurred during the exponential growth phase of bacteria (Fig. 3B, D). Moreover, a decline in bacterial activity coincided with an increase in viral abundance in both bays: in M-O, there was a negative relationship between VA and specific Vmax in the $0.8 \mu$ and $3 \mu$ treatments $\left(\log V A=4.11-0.63 \times \log V \max , r^{2}=0.15, n=60, p=0.002\right)$. This relationship was still significant $\left(\mathrm{r}^{2}=0.13, \mathrm{p}=0.007\right)$ when $20 \mu$ treatments were taken into account.

At the beginning of the incubations, the Eubacteria were less FISH-targeted in Arc (53\% of DAPI stained bacteria in $0.8 \mu-\operatorname{Tr}$ and $35 \%$ in $3 \mu-\operatorname{Tr})$ than in $\mathrm{M}-\mathrm{O}(62 \%$ in $0.8 \mu-\operatorname{Tr}$ and $81 \%$ in $3 \mu-$ Tr). In Arc, the dominance of $\gamma$-proteobacteria (Gamma) was further increased in the presence of small nanoflagellates (15\% versus $8 \%$ ), while $\alpha$ - and $\beta$-proteobacteria (Alpha and Beta) were present in relatively similar proportions (2-2.5\%) (Fig. 4). In M-O, Gamma were more numerous in the $0.8 \mu$ treatments $(8.9 \%)$ than in the $3 \mu$ treatments $(3 \%)$, while among the other groups, only Beta in $0.8 \mu$ - $\operatorname{Tr}$ showed up significantly $(2.6 \%)$.

Over 48h, the proportion of Eubacteria increased in both bays (78-85\% in Arc, $83-90 \%$ of total cells in M-O), with a dominance of Gamma. However, while the proportion of Gamma at $48 \mathrm{~h}$ 
311 was higher in Arc in the presence of flagellates $(70 \pm 5.4 \%)$ than in their absence $(58 \pm 3 \%)$,

312 independent of viral enrichment, Gamma dominated in $\mathrm{M}-\mathrm{O}(\approx 80 \%)$ with no difference between

313 treatments (Fig. 4). Furthermore, at $48 \mathrm{~h}$ in Arc, a positive effect of viruses was observed on Beta

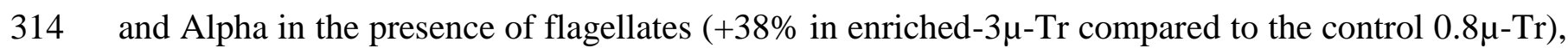

315 counterbalancing the negative impact of predators (-65\% in $3 \mu-\mathrm{Tr})$. However, earlier on, at $12 \mathrm{~h}$,

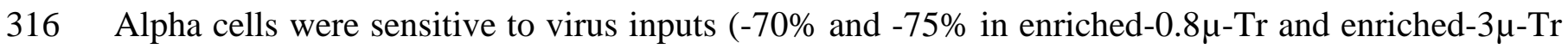

317 respectively, compared to the corresponding control). In $\mathrm{M}-\mathrm{O}$, among the rare groups, Alpha

318 increased notably in virus-enriched treatments without predators at $48 \mathrm{~h}(+50 \%$ in enriched- $0.8 \mu-\operatorname{Tr})$.

319 By contrast, nanoflagellates restrained their growth $(-49.6 \%$ in $3 \mu-\operatorname{Tr}$ compared to the $0.8 \mu-\operatorname{Tr}$

320 control), and even more so after viral enrichment (-76.2\% in enriched-3 $\mu$-Tr) (Fig. 4). Conversely,

321 the combined effect of nanoflagellates and viruses resulted in an increase of Beta cells at $12 \mathrm{~h}$

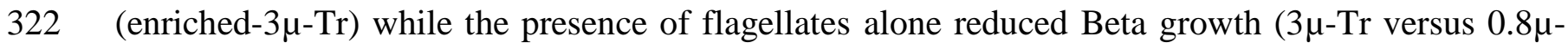

$323 \mathrm{Tr})$. At $48 \mathrm{~h}$, this pattern was reversed: Beta cells increased in the presence of flagellates $(+112 \%$

324 compared to the control) while they decreased with additional viral enrichment $(-50 \%)$.

\section{Discussion}

327 For each site, the survey concerned only one year without taking into account the potential inter328 annual variability of microbial dynamics in the pattern of trophic succession (Guarini et al., 2004; 329 Glé et al., 2007). Unfortunately, due to logistic restricitions, the comparison of the bays had to be 330 carried out for two adjacent years, and the bias of inter-annual variability cannot be assessed.

331 After in situ surveys of one year, 48h in vitro incubation experiments were performed with different 332 water categories treated by differential filtration, corresponding to a top-down manipulation of 333 microbial compartments and consequently the removal of predators. Because of the complexity of 334 the microbial food web, with parameters such as predation/competition links and the size overlap of 335 predators and competitors, the size-fractionation method may reduce or eliminate some elements of 336 normal trophic webs. Currently employed methods, including artificially composed trophic webs, 
necessarily simplify natural systems. We consider that, of those currently employed, the filtration method is one which involves the least disturbance of the webs (Chen et al., 2009).

\section{Temporal trophic succession}

Several previous studies have analysed seasonal production patterns in Arcachon Bay (Arc) (Robert et al., 1987; Glé et al., 2008) and Marennes Bay (M-O) (Guarini et al., 1998; Struski and Bacher, 2006). In Arc, river runoff and high levels of tidal exchange create a gradient of nutrients along the basin, except for phosphate (Glé et al., 2008). Seasonally, as in our study, Arc is early nutrient limited with a depletion of nitrate from May to the autumn and of phosphate during spring. In M-O, nutrient availability was higher and limitations were only encountered episodically during certain years (Soletchnik et al., 1998; Struski, 2005). However, during our 2006 in situ survey, no limitations were found. Based on our multivariate analysis, Arc is spatially heterogeneous while M$\mathrm{O}$ is spatially homogeneous, despite the influence of the Charente River. Moreover, as already illustrated by Soletchnik et al. (2007), seasonal variations, characterized by changes in salinity, temperature and chla are higher in M-O than in Arc.

Our trophic organization framework was based on microbiological and environmental dynamics, as proposed by Legendre and Rassoulzadegan (1995). Mousseau et al. (2001) illustrated the periodicity of trophic organization using ratios of biomasses, production and uptake rates. For the present study, the entire spectrum of abundance from virioplankton to mesozooplankton were used in a similar manner to Rodriguez et al. (2000). We used microbial abundance instead of biomass since the contact rates between virus/host cells or prey/predator determine viral infections and grazing rates. Our empirical trophic-period definitions were validated by a factorial discriminant analysis (FDA) in which the discriminant variable was the defined trophic model (Fig. S1). The clusters remained separated even in the absence of the abundance data used for characterizing the trophic organization (Lambda Wilks test, $\mathrm{p}<0.05$ ). 
The microbial food web dominated in the two bays for $54 \%$ and $43 \%$ of the seven months of the surveys in Arc and M-O, respectively; although this consisted of short periods of domination in M$\mathrm{O}$ and only 2 long ones in Arc. This domination was longer than what has been found in other coastal sites: on the Canadian East coast and in Plymouth Channel, the microbial food web dominated for less than $20 \%$ of the year and only during summer (Rodriguez et al., 2000; Mousseau et al., 2001). A herbivorous food web dominated in Canada for $50 \%$ of the year while it represented only 15\% (2 short phytoplankton blooms) in Plymouth Channel. In the latter, there was a domination of the transition model i.e. the multivorous food web. In our study sites, the herbivorous web persisted over longer periods in $\mathrm{M}-\mathrm{O}$ (43\% of the first seven months) while the transitional multivorous web dominated in Arc (22\% over the same period). The trophic systems of Arc, a largely closed lagoon, appear to be more stable and less subject to trophic variations than the more open M-O (Fig. 2; see also Fig. 4 in Soletchnik et al., (2007). In the latter, there was a succession of microbial and herbivorous models without a systematic passage through the transitional multivorous model. Moreover, the microbial food web was easier to distinguish from the other webs than in Arc (Fig. S1). Consequently, the dominance of the microbial food web attests the importance of microbial compartments in both ecosystems.

Another major difference between the bays is the contrasting trophic organization during winter: a herbivorous food web in Arc and a microbial food web in M-O. The presence of winter blooms has already been described in the Bay of Biscay (Labry et al., 2001; Marquis et al., 2007) and suggested for the two basins through analyses of long-term data series (Soletchnik et al., 2007). These phytoplankton blooms are influenced neither by temperature nor by nitrogen or phosphorus availability but are probably due to silicate input combined with a potential for salinity stratification or light availability.

The spring phytoplankton bloom occurred at the same period in both bays (April-May) yet it was greater in Arc, where it consisted of large phytoplankton forms such as diatoms and picoplankton. However, estimations of pelagic primary production illustrate a higher annual productivity in M-O 
of $185 \mathrm{gC} . \mathrm{m}^{-2} \cdot \mathrm{yr}^{-1}$ compared with $103 \mathrm{gC} \cdot \mathrm{m}^{-2} \cdot \mathrm{yr}^{-1}$ in Arc (Struski and Bacher, 2006; Glé et al., 389 2008).

\section{Grazing and viriolysis control}

392 Our results demonstrate that primary producers (small and large phytoplankton cells) and 393 autotrophy-based mechanisms (cf. PCA results) are important in Arcachon Bay (Arc). However, 394 Marennes Bay (M-O) is characterized by a higher potential for primary production, suggesting an 395 uncoupling between phytoplankton abundance and productivity. The difference in phytoplankton 396 abundance could be typically explained by (1) pelagic and benthic metazoan grazing, which is 397 relatively low in M-O (Sautour and Castel, 1998) compared to Arc; (2) flushing out, which is 398 relatively higher in M-O because it is quite an open system; (3) settling (Sautour and Castel, 1993); 399 (4) light limitation (Pomeroy and Deibel, 1986; Sautour and Castel, 1993) and trophic status (meso400 eutrophic in M-O vs. mesotrophic in Arc).

401 In addition, we show that in M-O, phytoplankton could also be controlled by viruses; this is corroborated by the simultaneous virus-bacteria uncoupling (Fig. 2). Viruses have been shown to modify the taxonomic diversity of their host communities, i.e. prokaryotes (Thingstad and Lignell, 1997), and protists (Suttle, 2007) restraining the rapidly growing and succeeding species. Moreover,

405 these successions of active phage-host systems would maintain a relatively constant baseline of host standing stocks (Wommack and Colwell, 2000). In addition, in M-O, virus infection could maintain the phytoplankton standing stock baseline at a low level. Thus, viral production may rely on 408 autotroph lysis as well as bacterial lysogeny events. Moreover, the in vitro experiments show that, 409 in the presence of protist predators, the potential for viral lysis of the bacteria standing stock was 410 lower in M-O (2.6\%) than in Arc (39\%) during the phytoplankton bloom. Indeed, viral control of 411 phytoplankton was less clear in Arc and the link between bacteria and viruses was strong. Without 412 nanoflagellates, the release of large numbers of free viruses was in line with an increase in bacterial 413 mortality of up to $70 \%$ of the bacterial standing stock, as already suggested by the contrasting 
dynamics of nanoflagellates and viruses during the in situ survey (Fig. 2; Table 2). In contrast, the 415 dynamics of nanoflagellates and viruses were similar in $\mathrm{M}-\mathrm{O}$, and during the spring bloom, virus416 mediated bacterial mortality did not change significantly $(9.4-13.6 \%$ with and without small 417 nanoflagellates, respectively).

418 Thus, the two trophic models that prevailed during the phytoplankton spring bloom are also 419 reflected in the interactions between the microbial compartments. The impact of nanoflagellates and 420 viruses on picoplankton differs in a multivorous web (Arc) compared to a herbivorous web (M-O).

421 The in vitro experiments carried out in Arc showed that the strong potential for viral bacteriolysis 422 (viral shunt: Wilhelm and Suttle, 1999) contributes to the development of picophytoeukaryotes 423 (picoeuk) due to an increased supply of organic and inorganic nutrients. The presence of 424 nanoflagellates, previously described as predators of picoeuk (Sherr and Sherr, 1994), appears to 425 counteract the indirect positive effect of viruses on the latter. Thus, the contrasting effect of viruses 426 and nanoflagellates on picoeuk can be defined as antagonist top-down control.

427 While the herbivorous web dominated in $\mathrm{M}-\mathrm{O}$, the antagonist impact could not be observed during in vitro experiments because of the very low abundance of picoeuk in the sampling water. The 429 bacterioplankton were the only picoplankton compartment affected by viral enrichment in M-O: 430 through the viral shunt, the absence of picoeuk reduces the competition for nutrients and thus 431 increases the positive effect of viral enrichment on the growth of non-lysed bacteria.

432 In our study, nanoflagellate treatment in both bays did not affect bacterial abundance or growth, in 433 contrast to published data (Zhang et al., 2007). However, this does not necessarily mean that 434 predation by nanoflagellates had no effect. Indeed, flagellate grazing on picoeuk in Arc potentially 435 released particulate organic matter, provoking the observed increase of bacterial proteolysis. 436 Furthermore, with size-selective predation, the loss of bacteria through grazing is compensated by 437 the growth of predation-resistant cells, suggesting that nanoflagellates can affect the phenotypic 438 structure of bacterioplankton (Gonzalez et al., 1990; Monger and Landry, 1991; Simek et al., 1997; 439 Posch et al., 1999). Moreover, considering the BCC data, the morphological diversity of bacteria 
and the mean biovolumes of bacterial sub-populations, there should be a preferential grazing of $\alpha$ proteobacteria (small coccoid-shaped cells) by nanoflagellates compared to $\beta$-proteobacteria (large bacillus-shaped cells). Beta dominate in freshwater but can also be found in coastal waters, without a defined marine or riverine origin (Nold and Zwart, 1998). Indeed, they are present in both bays in proportions equivalent to more specifically marine groups like Alpha during spring phytoplankton blooms. More specifically, the hypothesis that Alpha are more vulnerable to grazing is confirmed in M-O. Moreover, Beta are not as opportunistic as Gamma but nevertheless are metabolically very reactive: the sensitivity of Alpha to grazing and to viral infection provides nutrients for Beta, which are resistant, and this is highlighted by an increase of bacterial proteolysis.

However, Beta were as vulnerable to grazing as Alpha in Arc. A different clonal composition of Beta could explain the variable response to predation pressure between the two bays (Brümmer et al., 2003; Schwalbach et al., 2004).

The variable responses of bacterial groups to viral lysis in the present study confirm previous results concerning BCC (Bouvier and Del Giorgio, 2007) and bacterial metabolism (Middelboe et al., 1996). Consequently, viral production can be modified according to the trophic period. During the multivorous phase of the phytoplankton spring bloom in Arc, viral production was synergistically depleted by the presence of flagellates and viral enrichment. The predation of picoeuk and bacteria decreases the number of host cells and could lead to a general drop of lytic or lysogenic viral production. Moreover, the acquisition of viral resistance, as observed with Alpha bacteria in virusenriched incubation, would accentuate the negative impact on viral production. During the herbivorous phase of the phytoplankton spring bloom in $\mathrm{M}-\mathrm{O}$, the response in terms of viral production was the opposite. In the presence of flagellates, after virus enrichment, the development of predation-resistant and virus-sensitive Beta, at the expense of Alpha, led to a positive synergistic action of predators and viruses on viral production. This stimulation in the presence of flagellates has already been described (in contrast to the inhibition found in Arcachon) and explained by changes in BCC under grazing pressure (Simek et al., 2001; Weinbauer et al., 2003; Weinbauer et 
al., 2007; Pradeep Ram and Sime-Ngando, 2008). Interestingly, our results also suggest that this

467 stimulation occurs during the herbivorous period.

\section{Conclusion}

469 The temporal structure of trophic networks has been described in two bays on the French Atlantic coast, providing major new elements for future studies, in particular for comparing microbiological

471 relationships during similar trophic periods.

472 Considering that trophic periods were defined in the same way for the two bays, the results of 473 picoplankton and viral production can be extrapolated in relation to how multivorous and 474 herbivorous trophic models work in general. Thus, during a multivorous period, viral lysis together with flagellate grazing may reduce viral production and act antagonistically toward picoeukaryotes. During a herbivorous period, flagellates and virus could both stimulate viral production. These contrasting responses sustain the debate about potential shifts in viral production due to grazing: positive or undetectable responses have already been found (Hornak et al., 2005; Weinbauer et al., 2007). For the first time, a negative effect of flagellate predation and viral lysis on viral production has been described and linked to a trophic model, the multivorous food web.

\section{Experimental procedures}

Study site and sampling strategy of in situ surveys

484 The study was carried out in two sites along the Bay of Biscay on the French Atlantic coast, Arcachon Bay and Marennes Oleron Bay, which are $150 \mathrm{~km}$ apart. Both are shallow, soft-bottom bays that are under strong tidal influence (Fig. S2). Arcachon Bay $\left(44^{\circ} 40 \mathrm{~N}, 1^{\circ} 10 \mathrm{~W}\right)$ is a $180 \mathrm{~km}^{2}$ triangular shaped coastal lagoon that communicates with the Atlantic through a broad channel to the south (Fig. S2). The Leyre River is the major source of freshwater for the lagoon (100 $000 \mathrm{~m}^{3} \cdot \mathrm{y}^{-1}$; Glé et al., 2007) which has a meso- to macrotidal regime with amplitudes from $1.1 \mathrm{~m}$ to $4.9 \mathrm{~m}$. It is about $25 \mathrm{~m}$ deep at the entrance but the inside channels are shallow $(5-10 \mathrm{~m})$, while about $70 \%$ of the bay is covered by intertidal flats (Blanchet et al., 2008). The water residence time is more than 
3 weeks in the South East part of the bay. Marennes Oleron Bay to the North $\left(46^{\circ} 00 \mathrm{~N}, 1^{\circ} 10 \mathrm{~W}\right)$ is similar in size $\left(175 \mathrm{~km}^{2}\right)$ and depth (mean=8.6m; Stanisière et al., 2006), and intertidal mudflats cover about $60 \%$ of its surface (Fig. S2). Freshwater arrives mainly from the Charente River, with $3 \times 10^{9} \mathrm{~m}^{3} \cdot \mathrm{y}^{-1}$, or $90 \%$ of the total freshwater input (DDE-Charente Maritime/HYDRO-MEDD/DE). The bay is characterised by a macrotidal system, with amplitudes from 2 to $6 \mathrm{~m}$. It communicates with the ocean through two passes, the Pertuis de Maumusson to the South and the Pertuis d'Antioche to the North, with a relatively short residence time of 11 days. Tidal exchanges are greater through the northern pass, resulting in a north-south circulation of oceanic (Bay of Biscay) water (Struski, 2005).

Sampling was carried out twice weekly, from January to August 2005, at 2 stations in Arcachon Bay: B13, near the mouth of the Bay, which is under oceanic influence, and Comprian, in the inner basin, which is affected by the continental runoff. Five stations were surveyed in Marennes Oleron Bay on a bi-monthly basis (January to December 2006). The stations were spread out over the entire basin: one was close to the southern pass $(A=$ Auger $)$, two were above mudflats close to the continent $(\mathrm{Br}=\mathrm{Brouage})$ and island $(\mathrm{O}=$ Oleron $)$ coasts, one was close to the northern pass ( $\mathrm{B}=$ Boyard $)$ and one near the mouth of the Charente River $(\mathrm{C}=$ Charente).

Water samples were collected in both bays near the surface $(<1 \mathrm{~m})$ using Niskin bottles. Subsamples were fixed on board. The rest were kept in $8 \mathrm{~L}$ polypropylene dark bottles for laboratory analyses (transfer time $<3 \mathrm{~h}$ ). Physical parameters (temperature, salinity, $\mathrm{pH}$ ) were recorded on board with multiparameter probes (Seabird SBE25 in Arcachon and YSI 6600EDS-M in Marennes).

\section{Batch culture design}

Experimental water was collected at high tide at the surface from the central Comprian station in Arcachon Bay on 17 May 2006 and from the northern "E" station in Marennes Bay (Fig. S2) on 24 April 2007. The experimental protocols were based on a slightly modified version of the method of Auguet et al. (2009). In the lab, three water categories were obtained by sequential filtration from 
75L of seawater: (1) $<20 \mu \mathrm{m}$, filtered through nylon membranes, (2) $<3 \mu \mathrm{m}$, filtered through

519 Versapor acrylic polymer membranes (Gelman Sciences Inc.) and (3) <0.8um, filtered through 520 cellulose acetate membranes (Sartorius). Viral particles were then concentrated from 40L of $<0.2-$ 521 water, as a high molecular weight concentrate (HMWC) using a 30kDa polysulfone cartridge 522 (Sartorius). Viral-free water was kept for use as dilution water. Six different treatments were 523 prepared with the three water categories (Table 3), each diluted ten fold with the dilution water and 524 enriched (x2) or not with viruses (HMWC).

525 Each of the six treatments were triplicated in 2.4L Nalgene polycarbonate bottles filled with 2200 $526 \mathrm{ml}$ and incubated under in situ conditions of light and temperature in circulating seawater tanks. 527 Samples for bacterial, viral, phytoplankton and flagellate counts were collected at $0,6,12,18,24$, 52838 and $48 \mathrm{~h}$. Samples for bacterial activity and diversity were collected every $12 \mathrm{~h}$. Samples for 529 ciliate abundance were collected at the beginning and the end of the experiment $(<20 \mu \mathrm{m}$ treatment $)$.

\section{Physical and chemical parameters}

532 Seston was assessed by filtering 200 to $500 \mathrm{ml}$ of water according to turbidity and processed 533 according to Auguet et al. (2005). Samples for dissolved inorganic nutrients (Silicate (Si), 534 Phosphate $\left(\mathrm{PO}_{4}\right)$, Urea, Ammonium $\left(\mathrm{NH}_{4}\right)$, Nitrite $\left(\mathrm{NO}_{2}\right)$ and Nitrate $\left.\left(\mathrm{NO}_{3}\right)\right)$ were filtered $(20 \mathrm{ml}$, 535 Whatman GF/F) into glass flasks and stored at $-20^{\circ} \mathrm{C}$ for analyses with an autoanalyser (Bran and 536 Luebbe, AA3 for Arcachon and Skalar for Marennes (Strickland and Parsons, 1972)).

539 Chlorophyll $a$ (chla) and pheopigment were analysed by filtering $200 \mathrm{ml}$ of water through Whatman $540 \mathrm{GF} / \mathrm{F}$ filters $(25 \mathrm{~mm})$. Filters were stored for less than a month at $-20^{\circ} \mathrm{C}$ before extraction (acetone $54190 \%$ overnight at $4^{\circ} \mathrm{C}$ and shaken). Samples were analysed by the fluorimetry method (Turner, TD 542 700) according to Yentsch and Menzel (1963). 
543 Subsamples $(3 \mathrm{ml})$ for viral and bacterial counts were fixed with $0.02-\mu \mathrm{m}$ filtered formaldehyde $(2 \%$

544 final concentration) and stored for less than a week at $4^{\circ} \mathrm{C}$. Samples were enumerated by 545 epifluorescence microscopy after staining for 30 min with Sybr Green I (Noble and Fuhrman, 1998). 546 Bacteria and viruses were counted in at least 15 fields chosen randomly under blue excitation (Zeiss 547 Axioskop 1000x). Using flow cytometry (FACSCalibur, Bekton Dickinson) and Sybr-GreenI 548 staining, bacteria cells were distinguished between High Nucleic Acid (HNA) and Low Nucleic 549 Acid (LNA) cells. Furthermore, for batch culture samples, HNA cells were clustered in 4 sub550 groups (populations 3, 4, 5 and 6) according to decreasing biovolume (2, 0.8, 0.3 and $0.15 \mu \mathrm{m}^{3}$,

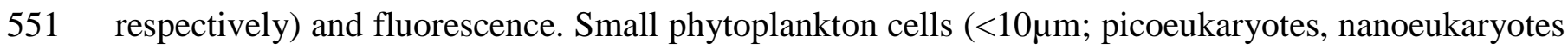
552 and Synechococcus) were analysed using flow cytometry according to Joux et al. (2005). 553 Microphytoplankton $(>10 \mu \mathrm{m})$ and ciliate subsamples were fixed and stained in alkaline lugol (final 554 concentration, 1\%). 10-20 ml subsamples were decanted in Utermöhl settling chambers before 555 counting and sizing by inverted microscopy (white light, Leica DMIRB, 400x - 630x). For ciliate 556 samples, the suspended matter of a 1L subsample was settled for $6 \mathrm{~h}$ at in situ temperature before 557 siphoning off the top $850 \mathrm{ml}$ and fixing a $150 \mathrm{ml}$ aliquot of the siphoned water. Nanoflagellates 558 (60ml) were fixed with paraformaldehyde (final concentration $1 \%$ ) and stored at $4{ }^{\circ} \mathrm{C}$ for less than a 559 week. Cells filtered onto $0.8 \mu \mathrm{m}$ black polycarbonate membranes (Nucleopore) were stained with 560 DAPI (Porter and Feig, 1980) and counted under ultraviolet excitation (Zeiss Axioskop 1000x) with 561 a distinction between unpigmented (HNF) and pigmented (ANF) nanoflagellates based on the 562 absence of chlorophyll fluorescence under green excitation. At least 100 nanoflagellates were 563 counted for each slide.

564 Mesozooplankton were collected $1 \mathrm{~m}$ below the surface in Arcachon Bay using a standard $200 \mu \mathrm{m}$ 565 WP-2 net towed slowly against the current. The catch was fixed in 5\% seawater/formalin and 566 counted with a binocular loupe. 
The maximum specific growth rate $\left(\mathrm{h}^{-1}\right)$ of bacteria was calculated from log transformed abundance data during the exponential growth phase in each bottle. Total viral production rate $\left(\mathrm{h}^{-1}\right)$ was calculated by adding the net increase of logarithmic viral abundance during each peak divided by the incubation time. The bacterial mortality $\left(\right.$ cell. $\left.\mathrm{ml}^{-1} \cdot \mathrm{h}^{-1}\right)$ induced by viral lysis was determined in unenriched treatments from the viral production (sum of the net increase of viral abundance divided by the duration of the experiment, particles. $\mathrm{ml}^{-1} \cdot \mathrm{h}^{-1}$ ) divided by an assumed burst size of 50 . The percentage of bacterial cells lysed $\left(\mathrm{d}^{-1}\right)$ was equivalent to the bacterial mortality rate $\left(\right.$ cell.ml $\left.\mathrm{m}^{-1} \cdot \mathrm{d}^{-1}\right)$ divided by the total bacterial abundance.

\section{Bacterial activity}

Leucine aminopeptidase activity was measured in duplicate at T0, 12, 24, 36 and T48h by using LLeucine-7-amino-4-methylcoumarin hydrochloride (Leu-MCA, Sigma) as a model protein substrate, according to Hoppe (1993). The enzyme Vmax was determined by adding substrate to the sample, giving a final saturating concentration of $1000 \mu \mathrm{M}$. Incubations were performed in the dark and at in situ temperature for around $5 \mathrm{~h}$, then stopped using Sodium-dodecyl sulfate ( $1 \%$ final concentration) The release of 7-amino-4-methylcoumarin dye (MCA, Sigma) was measured with a spectrofluorometer (Kontron, model SFM 25) at 380nm excitation and 440nm emission. Solutions of MCA (20 to $2000 \mathrm{nM}$ ) were used as a standard for calibration. The potential enzymatic activity per cell was obtained by dividing Vmax by the corresponding bacterial abundance (specific Vmax, fM.cell $\left.{ }^{-1} \cdot h^{-1}\right)$.

\section{Bacterial diversity}

Bacterial community composition was determined with fluorescent in situ hybridization using eight Cy-3 labelled probes (MWG-Biotech): a mix of Eub 338 I,II and III for Eubacteria, Pla5a for Planctomycetes, CF319a for Cytophaga-Flavobacterium cluster, Alf1b for $\alpha$-proteobacteria, Bet43a 

as a control (Amann et al., 1995; Bouvier and Del Giorgio, 2007).

597 Samples were fixed in paraformaldehyde (2\% final) and stored for at least $12 \mathrm{~h}$ at $4^{\circ} \mathrm{C}$ before 598 freezing at $-20^{\circ} \mathrm{C}$. Bacteria were filtered onto $0.2 \mu \mathrm{m}$ polycarbonate membranes (Whatman), rinsed 599 with $0.2 \mu \mathrm{m}$-filtered milli-Q water, dried and stored at $-20^{\circ} \mathrm{C}$. Pieces of membrane were hybridized 600 with $9 \mu \mathrm{l}$ of hybridization solution (Cy3-labelled probe, $2.5 \mathrm{ng} . \mu \mathrm{l}^{-1}$ ) for $4 \mathrm{~h} 30$ at $46^{\circ} \mathrm{C}$ and washed at $60148^{\circ} \mathrm{C}$ for $15 \mathrm{mn}$. The membrane was then rinsed for a few seconds successively in $0.2 \mu \mathrm{m}$-filtered 602 Milli-Q water then $80 \%$ ethanol and finally air dried. Bacterial cells were counter-stained with 603 DAPI mounting solution $\left(0.25 \mu \mathrm{g} . \mu \mathrm{l}^{-1}\right.$ in (Citifluor (Biovalley)/Vectashield (Ablys, SA, Paris): 4/1). 604 At least 10 fields were counted on an epifluorescence microscope (Axioskop, Zeiss) using Cy3 605 (blue) and DAPI (UV) filters.

Identification of trophic dynamics

608 Trophic periods were defined empirically using the 4 conceptual trophic flux models of Legendre 609 and Rassoulzadegan (1995), primarily from the abundances of phytoplankton and bacteria but also 610 taking into account the dynamics of viruses, HNF and ciliates (Table 4).

611 The herbivorous food web is characterized by blooms of large $(>10 \mu \mathrm{m})$ phytoplankton cells. During 612 this period there is in general an increase in the number of ciliates. The microbial food web is 613 defined by an increase of small autotrophs (phytoplankton <10 $\mu \mathrm{m}$ ) and heterotrophs (bacteria). 614 Their potential predators (HNF and ciliates) may increase in number. The microbial loop, a closed 615 system maintained by nutrient regeneration, is characterized by high abundance of exclusively 616 heterotrophic micro-organisms (bacteria, HNF and ciliates). Finally, the multivorous food web is a 617 transitional model where all trophic pathways are actively contributing to the dynamics of the 618 ecosystem.

619 The trophic organization identified for each bay was then formalized using multivariate factorial 620 discriminant analysis (FDA). FDA classifies the samples using predefined criteria (i.e. the trophic 
model) to discriminate samples according to independent variables (all abiotic and biotic parameters). Prior to the FDA analysis, data were normalized and tested for heteroskedasticity

623 (Levene test, Ho: equal variances between criteria). The purpose was to test whether samples are classified as predicted by the empirical trophic model and to assess the relative importance of the independent variables in the classification. The significance of clustering is tested by a Wilks Lambda test (low Lambda values corresponds to significant $(\mathrm{p}<0.05)$ clustering).

Statistical analysis

To compare field data between the 2 bays, the Arcachon results (3-day intervals) were regrouped by sliding means to obtain 15-day time steps, as in Marennes Bay. Statistical analyses were performed with log transformed data using XIStat (Addinsoft; version 7.5.2: one way- or two way-ANOVA, 632 simple regression, Principal Component Analysis (PCA) combined with Hierarchical Ascendant 633 Classification (HAC), Factorial Discriminant Analysis (FDA)) and Minitab (version 15: stepwise multiple regressions and Levene test for Heteroskedasticity).

\section{Acknowledgements}

This study was supported by the French Program PNEC-Littoral Atlantique. P.O.'s work was supported by a PhD fellowship from the CNRS and the Région Poitou-Charente. The authors thank the pilots of IFREMER-La Tremblade for the sampling logistics in Marennes Bay and Martine Bréret and Pascal Lebleu for their helpful technical assistance. We also thank two anonymous reviewers for their constructive criticism.

\section{References}

642 Allard, J., Chaumillon, E., and Féniès, H. (2009) A synthesis of morphological evolutions and 643 Holocene stratigraphy of a wave-dominated estuary: The Arcachon lagoon, SW France. Continental 644 Shelf Research.

645 Amann, R.I., Ludwig, W., and Schleifer, K.-H. (1995) Phylogenetic identification and in situ 646 detection of individual microbial cells without cultivation. Microbiological Reviews 59: 143-169.

647 Auguet, J.C., Montanie, H., Delmas, D., Hartmann, H.J., and Huet, V. (2005) Dynamic of 648 virioplankton abundance and its environmental control in the Charente estuary (France). Microbial 649 Ecology 50: 337-349. 
Auguet, J.C., Montanie, H., Hartmann, H.J., Lebaron, P., Casamayor, E.O., Catala, P., and Delmas, D. (2009) Potential effect of freshwater virus on the structure and activity of bacterial communities in the Marennes-Oléron Bay (France). Microbial Ecology 57: 295-306.

Azam, F., Fenchel, T., Field, J.G., Gray, J.S., Meyer-Reil, L.A., and Thingstad, T.F. (1983) The ecological role of water-column microbes in the sea. Marine Ecology Progress Series 10: 257-263.

Baudoux, A.-C., Veldhuis, M.J.W., Noordeloos, A.A.M., van Noort, G., and Brussaard, C.P.D. (2008) Estimates of virus- vs. grazing induced mortality of picophytoplankton in the North Sea during summer. Aquat Microb Ecol 52: 69-82.

658

659

660

661

662

663

664

665

666

667

668

669

670

671

672

673

674

675

676

677

678

679

680

681

682

683

684

685

686

687

688

689

690

691

692

Blanchet, H., Lavesque, N., Ruellet, T., Dauvin, J.C., Sauriau, P.G., Desroy, N. et al. (2008) Use of biotic indices in semi-enclosed coastal ecosystems and transitional waters habitats-Implications for the implementation of the European Water Framework Directive. Ecological Indicators 8: 360372.

Boehme, J., Frischer, M.E., Jiang, S.C., Kellogg, C.A., Pichrad, S., Rose, J.B. et al. (1993) Viruses, bacterioplankton, and phytoplankton in the southeastern Gulf of mexico: distribution and contribution to oceanic DNA pools. Marine ecology progress series 97: 1-10.

Boras, J.A., Sala, M.M., Vazquez-Dominguez, E., Weinbauer, M.G., and Vaqué, D. (2009) Annual changes of bacterial mortality due to viruses and protists in an oligotrophic coastal environment (NW Mediterranean). Environmental Microbiology 11: 1181-1193.

Borsheim, K.Y., Bratbak, G., and Heldal, M. (1990) Enumeration and biomass estimation of planktonic bacteria and viruses by transmission electron microscopy. Applied and environmental microbiology 56: 352-356.

Bouvier, T., and Del Giorgio, P.A. (2007) Key role of selective viral-induced mortality in determining marine bacterial community composition. Environmental Microbiology 9: 287-297.

Brümmer, I.H.M., Felske, A., and Wagner-Döbler, I. (2003) Diversity and seasonal variability of beta-proteobacteria in biofilms of polluted rivers: analysis by temperature gradient gel electrophoresis and cloning. Applied and environmental microbiology 69: 4463-4473.

Calbet, A., and Saiz, E. (2005) The ciliate-copepod link in marine ecosystems. Aquatic Microbial Ecology 38: 157-167.

Chen, B., Liu, H., and Wang, Z. (2009) Trophic interactions within the microbial food web in the South China Sea revealed by size-fractionation method. Journal of Experimental Marine Biology and Ecology 368: 59-66.

Cottrell, M.T., and Suttle, C.A. (1995) Dynamics of a lytic virus infecting the photosynthetic marine picoflagellate Micromonas pusilla. Limnology and Oceanography 40: 730-739.

Fuhrman, J.A. (1999) Marine viruses and their biogeochemical and ecological effects. Nature 399: 541-548.

Fuhrman, J.A. (2009) Microbial community structure and its functional implications. Nature 459: 193-199.

Garza, D.R., and Suttle, C.A. (1995) Large double-stranded DNA viruses which cause the lysis of a marine heterotrophic nanoflagellate (Bodo sp.) occur in natural marine viral communities. Aquatic Microbial Ecology 9: 203-210.

Gasol, J.M., Pedros-Alio, C., and Vaque, D. (2002) Regulation of bacterial assemblages in oligotrophic plankton systems: results from experimental and empirical approaches. Antonie Van Leeuwenhoek 81: 435-452. 
Glé, C., Del Amo, Y., Sautour, B., Laborde, P., and Chardy, P. (2008) Variability of nutrients and phytoplankton primary production in a shallow macrotidal coastal ecosystem (Arcachon Bay, France). Estuarine, Coastal and Shelf Science 76: 642-656.

Glé, C., Del Amo, Y., Bec, B., Sautour, B., Froidefond, J.-M., Gohin, F. et al. (2007) Typology of environmental conditions at the onset of winter phytoplankton blooms in a shallow macrotidal coastal ecosystem, Arcachon Bay (France). Journal of Plankton Ressearch 29: 999-1014.

Gonzalez, J.M., Sherr, E.B., and Sherr, B.F. (1990) Size-selective grazing on bacteria by natural assemblages of estuarine flagellates and ciliates. Applied and environmental microbiology 56: 583589.

Guarini, J.-M., Gros, P., Blanchard, G.F., Richard, P., and Fillon, A. (2004) Benthic contribution to pelagic microalgal communities in two semi-enclosed, European-type littoral ecosystems (Marennes-Oléron Bay and Aiguillon Bay, France). Journal of Sea Research 52: 241-258.

Guarini, J.-M., Blanchard, G.F., Bacher, C., Gros, P., Riera, P., Richard, P. et al. (1998) Dynamics of spatial patterns of microphytobenthic biomass: inferences from a geostatistical analysis of two comprehensive surveys in Marennes-Oléron Bay (France). Marine Ecology Progress Series 166: 131-141.

Guixa-Boixereu, N., Vaqué, D., Gasol, J.M., and Pedros-Alio, C. (1999) Distribution of viruses and their potential effect on bacterioplankton in an oligotrophic marine system. Aquat Microb Ecol 19: 205-213.

Hahn, M.W., and Hofle, M.G. (2001) Grazing of protozoa and its effect on populations of aquatic bacteria. FEMS Microbiology Ecology 35: 113-121.

Hennes, K., P., and Suttle, C.A. (1995) Direct counts of viruses in natural waters and laboratory cultures by epifluorescence microscopy. Limnology and Oceanography $\mathbf{4 0 .}$

Hirose, M., Katano, T., and Nakano, S.-I. (2008) Growth and grazing mortality rates of Prochlorococcus, Synechococcus and eukaryotic picophytoplankton in the bay of the Uwa Sea, Japan. Journal of Plankton Research 30: 241-250.

Hoppe, H.G. (1993) Use of fluorogenic model substrates for extracellular enzyme activity (EEA) of bacteria. In Handbook of methods in Aquatic Microbial Ecology. Kemp, P.F., Sherr, B.F., Sherr, E.B., and Cole, J.J. (eds). Boca Raton, FL: Lewis Publishers, pp. 423-431.

Hornak, K., Masin, M., Jezbera, J., Bettarel, Y., Nedoma, J., Sime-Ngando, T., and Simek, K. (2005) Effects of decreased resource availability, protozoan grazing and viral impact on the structure of bacterioplankton assemblage in a canyon-shaped reservoir. FEMS Microbiology Ecology 52: 315327.

Joux, F., Servais, P., Naudin, J.-J., Lebaron, P., Oriol, L., and Courties, C. (2005) Distribution of picophytoplankton and bacterioplankton along a river plume gradient in the Mediterranean Sea. Vie et Milieu 55: 197-208.

Kirchman, D.L., Meon, B., Cottrell, M.T., Hutchins, D.A., Weeks, D., and Bruland, K.W. (2000) Carbon versus iron limitation of bacterial growth in the California upwelling regime. Limnol Oceanogr 45: 1681-1688.

Labry, C., Herbland, A., Delmas, D., Laborde, P., Lazure, P., Froidefond, J.-M. et al. (2001) Initiation of winter phytoplankton blooms within the Gironde plume waters in the Bay of Biscay. Marine Ecology Progress Series 212: 117-130.

Legendre, L., and Rassoulzadegan, F. (1995) Plankton and nutrient dynamics in marine waters. Ophelia 41: 153-172.

Li, W.K.W. (1998) Annual average abundance of heterotrophic bacteria and Synechococcus in surface ocean waters. Limnology and Oceanography 43: 1746-1753. 
Maranger, R., Bird, D.F., and Juniper, S.K. (1994) Viral and bacterial dynamics in Arctic sea ice during the spring algal bloom near Resolute, N.W.T., Canada. Marine Ecology Progress Series 111: 121-127.

Marquis, E., Niquil, N., Delmas, D., Hartmann, H.J., Bonnet, D., Carlotti, F. et al. (2007) Inverse analysis of the planktonic food web dynamics related to phytoplankton bloom development on the continental shelf of the Bay of Biscay, French coast. Estuarine, Coastal and Shelf Science 73: 223235.

Massana, R., Del Campo, J., Dinter, C., and Sommaruga, R. (2007) Crash of a population of the marine heterotrophic flagellate Cafeteria roenbergensis by viral infection. Environmental Microbiology 9: 2660-2669.

Middelboe, M., Jorgensen, N.O.G., and Kroer, N. (1996) Effects of viruses on nutrients turnover and growth efficiency of non-infected marine bacterioplankton. Applied and Environmental Microbiology 62: 1991-1997.

Monger, B.C., and Landry, M.R. (1991) Prey-size dependency of grazing by free-living marine flagellates. Marine Ecology Progress Series 74: 239-248.

Monger, B.C., Landry, M.R., and Brown, S.L. (1999) Feeding selection of heterotrophic marine nanoflagellates based on the surface hydrophobicity of their picoplankton prey. Limnology and Oceanography 44: 1917-1927.

Mousseau, L., Klein, B., Legendre, L., Dauchez, S., Tamigneaux, E., Tremblay, J.-E., and Grant Ingram, R. (2001) Assessing the trophic pathways that dominate planktonic food webs: an approach based on simple ecological ratios. Journal of Plankton research 23: 765-777.

Nielsen, T.G., and Kiorboe, T. (1994) Regulation of zooplankton biomass and production in a temperate, coastal system. 2. Ciliates. Limnology and Oceanography 39: 508-519.

Noble, R.T., and Fuhrman, J.A. (1998) Use of SYBR Green I for rapid epifluorescence counts of marine viruses and bacteria. Aquatic Microbial Ecology 14: 113-118.

Nold, S., and Zwart, G. (1998) Patterns and governing forces in aquatic microbial communities. Aquatic Ecology 32: 17-35.

Platt, T., Subba Rao, D.V., and Irwin, B. (1983) Photosynthesis of picoplankton in the oligotrophic ocean. Nature 301: 702-704.

Pomeroy, L.R., and Deibel, D. (1986) temperature regulation of bacterial activity during the spring bloom in newfoundland coastal waters. Science 233: 359-361.

Porter, K.G., and Feig, Y.S. (1980) The use of DAPI for identifying and counting aquatic microflora. Limnology and Oceanography 25: 943-948.

Posch, T., Jezbera, J., Vrba, J., Simek, K., Pernthaler, J., Andreatta, S., and Sonntag, B. (2001) Size selectivity feeding in Cyclidium glaucoma (Ciliophora, Scuticociliatida) and its effects on bacterial community structure: a study from a continuous cultivation system. Microbial Ecology 42: 217-227.

Posch, T., Simek, K., Vrba, J., Pernthaler, J., Nedoma, J., Sattler, B. et al. (1999) Predator-induced changes of bacterial size-structure and productivity studied on an experimental microbial community. Aquatic microbial ecology 18: 235-246.

Pradeep Ram, A., and Sime-Ngando, T. (2008) Functional responses of prokaryotes and viruses to grazer effects and nutrient additions in freshwater microcosms. The ISME Journal 2: 498-509.

Rivkin, R.B., Legendre, L., Deibel, D., Tremblay, J.-E., Klein, B., Crocker, K. et al. (1996) Vertical flux of biogenic carbon in the ocean: Is there food web control? Science 272: 1163-1166.

Robert, R., Guillocheau, N., and Collos, Y. (1987) Hydrobiological parameters during an annual cycle in the Arcachon Basin. Marine Biology 95: 631-640. 
Rodriguez, F., Fernandez, E., Head, R.N., Harbour, D.S., Bratbak, G., Heldal, M., and Harris, R.P. (2000) Temporal variability of viruses, bacteria, phytoplankton and zooplankton in the western English Channel off Plymouth. Journal of the Marine Biological Association of UK 80: 575-586.

Sanders, R.W., Caron, D.A., and Berninger, U.G. (1992) Relationships between bacteria and heterotrophic nanoplankton in marine and fresh waters: an inter-ecosystem comparison. Marine ecology progress series 86 : $1-14$.

Sautour, B., and Castel, J. (1993) Distribution of zooplankton populations in Marennes-Oléron Bay (France), structure and grazing impact of copepod communities. Oceanologica Acta 16: 279-290.

Sautour, B., and Castel, J. (1998) Importance of microzooplanktonic crustaceans in the coastal food chain: Bay of Marennes-Oléron, France. Oceanologica Acta 21: 105-112.

Schwalbach, M.S., Hewson, I., and Fuhrman, J.A. (2004) Viral effects on bacterial community composition in marine plankton microcosms. Aquatic Microbial Ecology 34: 117-127.

Sherr, E.B., and Sherr, B.F. (1988) Role of microbes in pelagic food webs: A revised concept. Limnology and Oceanography 33: 1225-1227.

Sherr, E.B., and Sherr, B.F. (1994) Bacterivory and herbivory: Key roles of phagotrophic protists in pelagic food web. Microbial Ecology 28: 223-235.

Simek, K., Vrba, J., Pernthaler, J., Posch, T., Hartman, P., Nedoma, J., and Psenner, R. (1997) Morphological and Compositional Shifts in an Experimental Bacterial Community Influenced by Protists with Contrasting Feeding Modes. Applied and Environmental Microbiology 63: 587-595.

Simek, K., Pernthaler, J., Weinbauer, M.G., Hornak, K., Dolan, J.R., nedoma, J. et al. (2001) Changes in bacterial community composition and dynamics and viral mortality rates associated with enhanced flagellate grazing in mesoeutrophic reservoir. Applied and environmental microbiology 67: 2723-2733.

Soletchnik, P., Faury, N., Razet, D., and Goulletquer, P. (1998) Hydrobiology of the MarennesOléron Bay. Seasonal indices and analysis of trends from 1978 to 1995. Hydrobiologia 386: 131146.

Soletchnik, P., Ropert, M., Mazurié, J., Fleury, P.G., and Le Coz, F. (2007) Relationships between oyster mortality patterns and environmental data from monitoring databases along the coasts of France. Aquaculture 271: 384-400.

Stanisière, J.-Y., Dumas, F., Plus, M., Maurer, D., and Robert, S. (2006) Caractérisation des composantes hydrodynamiques d'un système côtier semi-fermé: Le Bassin de Marennes-Oléron. In Thème 1: Caractérisation des forçages hydrodynamiques. Atlantique, P.-C.L.A.m.d.f.d.s.s.-f.d.1. (ed).

Strickland, J.D.H., and Parsons, T.R. (eds) (1972) A practical handbook of seawater analysis: Fishery Research Board Canada.

Struski, C. (2005) Modélisation des flux de matières dans la baie de Marennes-Oléron: Couplage de l'hydrodynamisme, de la production primaire et de la consommation par les huîtres. Thèse de doctorat d'état. Université de La Rochelle: $306 \mathrm{p}$.

Struski, C., and Bacher, C. (2006) Preliminary estimate of primary production by phytoplankton in Marennes-Oléron Bay, France. Estuarine, Coastal and Shelf Science 66: 323-334.

Suttle, C.A. (2005) Viruses in the sea. Nature 437: 356-361.

Suttle, C.A. (2007) Marine viruses-major players in the global ecosystem. Nature Reviews Microbiology 5: 801-812.

Thingstad, T.F., and Lignell, R. (1997) Theoretical models for the control of bacterial growth rate, abundance, diversity and carbon demand. Aquatic microbial ecology 13: 19-27. 
829 Weinbauer, M.G., Christaki, U., Nedoma, J., and Simek, K. (2003) Comparing the effects of 830 resource enrichment and grazing on viral production in a meso-eutrophic reservoir. Aquatic 831 Microbial Ecology 31: 137-144.

832 Weinbauer, M.G., Hornak, K., Jezbera, J., Nedoma, J., Dolan, J.R., and Simek, K. (2007) 833 Synergistic and antagonistic effects of viral lysis and protistan grazing on bacterial biomass, 834 production and diversity. Environmental Microbiology 9: 777-788.

835 Wilhelm, S.W., and Suttle, C.A. (1999) Viruses and nutrient cycles in the sea. Bioscience 49: 781836788.

837 Winter, C., Smit, A., Herndl, G.J., and Weinbauer, M.G. (2004) Impact of virioplankton on archaeal 838 and bacterial community richness as assessed in seawater batch cultures. Applied and 839 environmental microbiology 70: 804-813.

840 Wommack, K.E., and Colwell, R.R. (2000) Virioplankton: Viruses in aquatic ecosystems. 841 Microbiology and molecular biology reviews 64: 69-114.

842 Yentsch, C.S., and Menzel, D.W. (1963) A method for the determination of phytoplankton 843 chlorophyll and pheophytin by fluorescence. Deep-sea Research 10: 221-231.

844 Zhang, R., Weinbauer, M.G., and Qian, P.Y. (2007) Viruses and flagellates sustain apparent 845 richness and reduce biomass accumulation of bacterioplankton in coastal marine waters. 846 Environmental Microbiology 9: 3008-3018. 


\section{Table and figure legends:}

Table 1: Annual means and simple linear regressions between bacterioplankton (BA) and virioplankton (VA) at the sampling stations of Marennes Oléron Bay (2006) and Arcachon Bay (2005). Linear regressions were performed with log transformed data.

\begin{tabular}{|c|c|c|c|c|c|c|c|}
\hline & Stations & BA (cells.ml $\left.{ }^{-1}\right)$ & VA (particles.ml ${ }^{-1}$ ) & Equation & $\mathrm{r}^{2}$ & $\mathrm{p}$ & $\mathrm{n}$ \\
\hline \multirow[t]{5}{*}{ Marennes } & Auger & $\begin{array}{c}4.04 \times 10^{6} \\
\left(\min -8.70 \times 10^{5} / \max -1.01 \times 10^{7}\right)\end{array}$ & $\begin{array}{c}3.18 \times 10^{7} \\
\left(\min -5.24 \times 10^{6} / \mathrm{max}-5.97 \times 10^{7}\right)\end{array}$ & $\log \mathrm{BA}=1.5 \log \mathrm{VA}-4.7$ & 0.60 & $<0.0001$ & 20 \\
\hline & Boyard & $\begin{array}{c}3.95 \times 10^{6} \\
\left(\min -1.01 \times 10^{6} / \mathrm{max}-1.30 \times 10^{6}\right)\end{array}$ & $\begin{array}{c}3.36 \times 10^{7} \\
\left(\min -1.82 \times 10^{7} / \mathrm{max}-5.59 \times 10^{7}\right)\end{array}$ & $\log \mathrm{BA}=1.45 \log \mathrm{VA}-4.39$ & 0.46 & 0.001 & 20 \\
\hline & Charente & $\begin{array}{c}4.60 \times 10^{6} \\
\left(\min -1.16 \times 10^{6} / \max -1.17 \times 10^{7}\right)\end{array}$ & 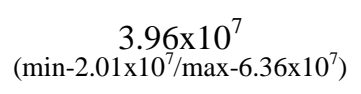 & $\log \mathrm{BA}=0.84 \log \mathrm{VA}+0.23$ & 0.18 & 0.092 & 17 \\
\hline & Oléron & $\begin{array}{c}3.70 \times 10^{6} \\
\left(\min -1.05 \times 10^{6} / \mathrm{max}-9.03 \times 10^{6}\right)\end{array}$ & $\begin{array}{c}3.07 \times 10^{7} \\
\left(\min -1.82 \times 10^{7} / \mathrm{max}-5.07 \times 10^{7}\right)\end{array}$ & $\log \mathrm{BA}=1.74 \log \mathrm{VA}-6.51$ & 0.45 & 0.001 & 20 \\
\hline & Brouage & $\begin{array}{c}4.28 \times 10^{6} \\
\left(\min -7.10 \times 10^{5} / \max -1.8 \times 10^{7}\right)\end{array}$ & 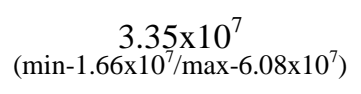 & $\log \mathrm{BA}=1.6 \log \mathrm{VA}-5.5$ & 0.51 & 0.001 & 19 \\
\hline \multirow[t]{2}{*}{ Arcachon } & B13 & $\begin{array}{c}1.05 \times 10^{6} \\
\left(\min -3.10 \times 10^{5} / \max -1.58 \times 10^{6}\right)\end{array}$ & $\begin{array}{c}4.48 \times 10^{6} \\
\left(\min -7.50 \times 10^{5} / \max -8.11 \times 10^{6}\right)\end{array}$ & $\log \mathrm{BA}=0.6 \log \mathrm{VA}+2.06$ & 0.83 & $<0.0001$ & 31 \\
\hline & Comprian & $\begin{array}{c}1.32 \times 10^{6} \\
\left(\min -5.00 \times 10^{5} / \mathrm{max}^{2}-38 \times 10^{6}\right)\end{array}$ & 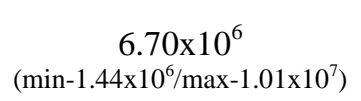 & $\log \mathrm{BA}=0.47 \log \mathrm{VA}+2.93$ & 0.60 & $<0.0001$ & 31 \\
\hline
\end{tabular}


Table 2. Stepwise linear regression of bacteria, virus, flagellate and ciliate abundance according to environmental parameters in Arcachon and Marennes bays for the entire year and according to the season. The seasons were defined based on the PCA results. Descriptors: BA: Bacterial abundance, VA: Viral abundance, HNF: Heterotrophic nanoflagellate abundance, ANF: Autotrophic nanoflagellate abundance, HNA: Abundance of high nucleic acid bacteria, Cil: Ciliate abundance, Pico: Picoplankton abundance, Nano: Nanoplankton abundance, Syn: Synechococcus abundance, Dino: Dinophyceae abundance, Diat: Diatom abundance, Cop: Copepods abundance $\mathrm{T}^{\circ} \mathrm{w}$ : Water temperature, S\%: Salinity, Crypto: Cryptophyceae abundance, Seston Org: Organic seston concentration, $\mathrm{NH}_{4}$ : Ammonium, $\mathrm{PO}_{4}$ : Phosphate, $\mathrm{NO}_{2}$ : Nitrite, Chla: Chlorophyll $a$ concentrations, Pheo: Pheopigment concentrations. Logarithmic transformations were applied to all data. The coefficient of determination (adjusted $\mathbf{r}^{2}$ ) was corrected according to the number of variables used in the regression. Copepods were analysed only at Arcachon and taken into account in stepwise regression analysis, but their inclusion does not interfere with regression results except for HNF in winter. Bold parameters are discussed in the text.

\begin{tabular}{|c|c|c|c|}
\hline & Multiple regression equations & $\mathrm{r}^{2}$ adjusted & $\mathrm{n}$ \\
\hline Annual & 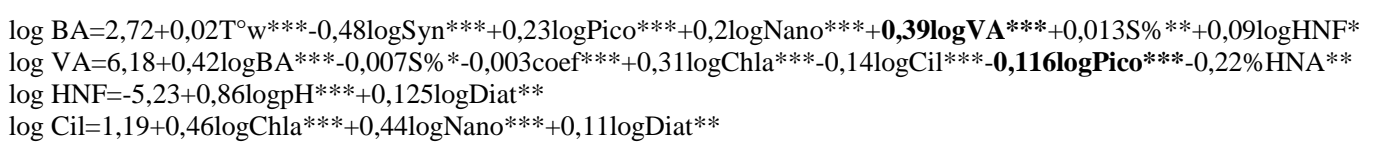 & $\begin{array}{l}90.70 \\
71.02 \\
23.68 \\
60.15\end{array}$ & $\begin{array}{l}84 \\
84 \\
84 \\
84\end{array}$ \\
\hline Winter & 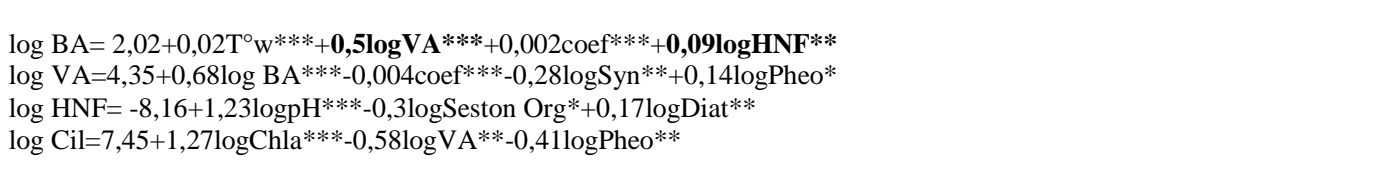 & $\begin{array}{l}81.21 \\
77.31 \\
47.01 \\
47.87\end{array}$ & $\begin{array}{l}40 \\
40 \\
40 \\
40\end{array}$ \\
\hline Summer & 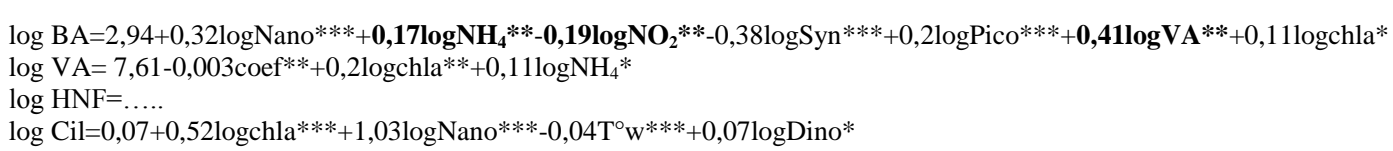 & $\begin{array}{l}74.8 \\
27.21 \\
71.64\end{array}$ & $\begin{array}{l}44 \\
44 \\
44 \\
44\end{array}$ \\
\hline Annual & 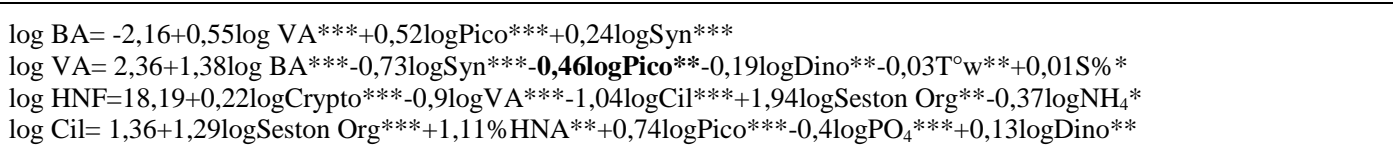 & $\begin{array}{l}94.11 \\
92.83 \\
84.16 \\
97.38\end{array}$ & $\begin{array}{l}31 \\
31 \\
31 \\
31\end{array}$ \\
\hline Winter & 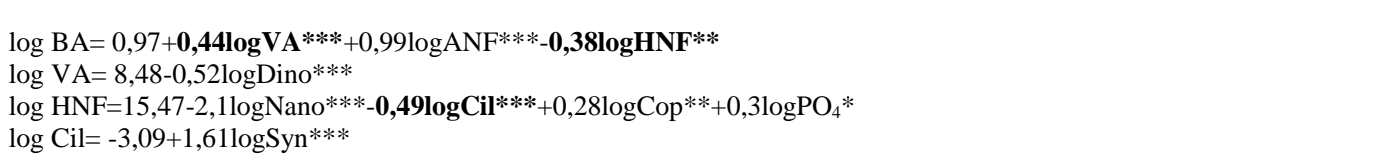 & $\begin{array}{l}91.04 \\
64.67 \\
94.96 \\
82.23\end{array}$ & $\begin{array}{l}14 \\
14 \\
14 \\
14\end{array}$ \\
\hline Summer & 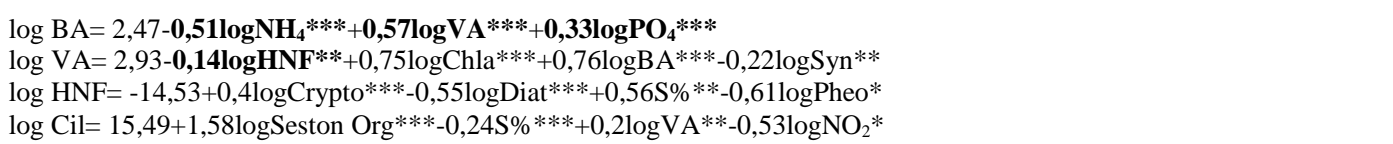 & $\begin{array}{l}95.86 \\
96.71 \\
92.83 \\
98.16\end{array}$ & $\begin{array}{l}17 \\
17 \\
17 \\
17\end{array}$ \\
\hline
\end{tabular}


Table 3. Description of treatments used in batch culture experiments, with abbreviations employed 878 in the text.

\begin{tabular}{|c|c|c|c|}
\hline Water category & Organisms & Treatment & Abbreviation \\
\hline \multirow{2}{*}{$<0.8 \mu \mathrm{m}$} & \multirow{2}{*}{$\begin{array}{c}\text { Bacteria Virus } \\
\text { Picophytoeukaryotes }\end{array}$} & Control & $0.8 \mu-T r$ \\
\hline & & Virus enriched & 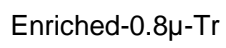 \\
\hline \multirow{2}{*}{$<3 \mu \mathrm{m}$} & \multirow{2}{*}{ + Small nanoflagellates } & Control & $3 \mu-\operatorname{Tr}$ \\
\hline & & Virus enriched & Enriched-3 $\mu-T r$ \\
\hline \multirow{2}{*}{$<20 \mu \mathrm{m}$} & \multirow{2}{*}{ + Large flagellates } & Control & $20 \mu-\operatorname{Tr}$ \\
\hline & & Virus enriched & Enriched-20 $\mu-T r$ \\
\hline
\end{tabular}

Table 4. Definitions of the characteristics of the four trophic models defined by Legendre and Rassoulzadegan (1995) and according to Rodriguez et al. (2000) and Mousseau et al. (2001). Arrows describe the abundance dynamics of the biological compartments (increasing, decreasing or fluctuating). ** Major parameters taken into account for the definition of trophic periods; * secondary parameters. HNF: unpigmented nanoflagellates.

\begin{tabular}{|c|c|c|c|c|c|c|}
\hline Trophic model & $\begin{array}{c}\text { Large } \\
\text { phytoplankton } \\
(>10 \mu \mathrm{m}) * *\end{array}$ & $\begin{array}{c}\text { Small } \\
\text { phytoplankton } \\
(<10 \mu \mathrm{m}) * *\end{array}$ & Bacteria*** & Virus* & $\mathrm{HNF}^{*}$ & Ciliates* \\
\hline $\begin{array}{l}\text { Herbivorous } \\
\text { food web }\end{array}$ & & & & & & \\
\hline \multicolumn{7}{|l|}{$\begin{array}{l}\text { Multivorous } \\
\text { food web }\end{array}$} \\
\hline \multicolumn{7}{|l|}{$\begin{array}{l}\text { Microbial } \\
\text { food web }\end{array}$} \\
\hline $\begin{array}{l}\text { Microbial } \\
\text { loop }\end{array}$ & & & & & & \\
\hline
\end{tabular}


Table S1. Mean, minimum and maximum values of the abiotic and chlorophyll $a$ parameters, with dates, at Marennes Bay (4 inner stations: A, B, O, $\mathrm{Br}$ and one riverine station: $\mathrm{C}) . \mathrm{C}$ was analysed separately because of the significant differences compared to the four other stations $\left(\mathrm{H}_{0}\right.$ rejected in a

Tukey multiple comparison test). The seasons were defined based on the clustering of stations using PCA. Winter season: January to 5 April and

November-December 2006. The remainder of the year was considered as the summer season. Runoff data were supplied by DDE-Charente 898

Maritime/HYDRO-MEDD/DE for the Charente River.

\begin{tabular}{|c|c|c|c|c|c|c|}
\hline Marennes & Mean & $\begin{array}{l}\text { Winter } \\
\text { Min/date }\end{array}$ & Max/date & Mean & $\begin{array}{l}\text { Summe } \\
\text { Min/date }\end{array}$ & Max/date \\
\hline $\begin{array}{c}\text { Water temperature }\left({ }^{\circ} \mathrm{C}\right) \\
\mathrm{A}, \mathrm{B}, \mathrm{O}, \mathrm{Br} \\
\mathrm{C}\end{array}$ & $\begin{array}{l}9.19 \\
8.59 \\
\end{array}$ & $\begin{array}{l}\text { 5.1/1Mar. } \\
\text { 4.8/7 Feb. }\end{array}$ & $\begin{array}{l}14.5 / 28 \text { Nov. } \\
12.9 / 28 \text { Nov. }\end{array}$ & $\begin{array}{l}18.74 \\
19.67 \\
\end{array}$ & $\begin{array}{l}\text { 13.3/2 May } \\
\text { 13.6/2 May }\end{array}$ & $\begin{array}{l}24.7 / 26 \mathrm{Jul} . \\
24.8 / 26 \mathrm{Jul} .\end{array}$ \\
\hline $\begin{array}{c}\text { Salinity }(\mathrm{PSU}) \\
\mathrm{A}, \mathrm{B}, \mathrm{O}, \mathrm{Br} \\
\mathrm{C}\end{array}$ & $\begin{array}{l}31.96 \\
20.61\end{array}$ & $\begin{array}{l}\text { 28.3/4 Apr. } \\
\text { 10.4/1 Mar. }\end{array}$ & $\begin{array}{l}\text { 34.3/7 Nov. } \\
\text { 29.8/24 Jan. }\end{array}$ & $\begin{array}{c}33.86 \\
28.2\end{array}$ & $\begin{array}{c}31 / 25 \text { Apr. } \\
12.7 / 25 \text { Apr. }\end{array}$ & $\begin{array}{l}\text { 35.3/24 Aug. } \\
\text { 33.9/l Aug. }\end{array}$ \\
\hline $\begin{array}{c}\text { Nitrate }(\mu \mathrm{M}) \\
\text { A,B,O,Br } \\
\text { C }\end{array}$ & $\begin{array}{l}42.40 \\
90.76 \\
\end{array}$ & $\begin{array}{l}\text { 12.09/12 Dec. } \\
\text { 46.95/7 Nov. }\end{array}$ & $\begin{array}{l}\text { 97.98/28 Nov. } \\
\text { 192.9/12 Dec. }\end{array}$ & $\begin{array}{l}15.12 \\
47.46 \\
\end{array}$ & $\begin{array}{l}0.53 / 1 \text { Aug. } \\
6.65 / 1 \text { Aug. }\end{array}$ & $\begin{array}{l}\text { 78.17/25 Apr. } \\
\text { 167.5/25 Apr. }\end{array}$ \\
\hline $\begin{array}{c}\text { Ammonium }(\mu \mathrm{M}) \\
\mathrm{A}, \mathrm{B}, \mathrm{O}, \mathrm{Br} \\
\mathrm{C} \\
\end{array}$ & $\begin{array}{c}7.16 \\
13.07 \\
\end{array}$ & $\begin{array}{c}0.01 / 12 \text { Dec. } \\
1.15 / 18 \text { Jan. }\end{array}$ & $\begin{array}{l}\text { 68.62/28 Nov. } \\
\text { 68.83/12 Dec. }\end{array}$ & $\begin{array}{l}2.43 \\
2.66 \\
\end{array}$ & $\begin{array}{l}0.35 / 25 \text { Apr. } \\
0.41 / 14 \text { Jun. }\end{array}$ & $\begin{array}{c}\text { 18.85/24 Aug. } \\
\text { 7.4/25 Apr. }\end{array}$ \\
\hline $\begin{array}{c}\text { Phosphate }(\mu \mathrm{M}) \\
\text { A,B,O,Br } \\
\text { C } \\
\end{array}$ & $\begin{array}{l}0.97 \\
1.25 \\
\end{array}$ & $\begin{array}{c}0.5 / 5 \text { Apr. } \\
0.77 / 12 \text { Dec. }\end{array}$ & $\begin{array}{l}\text { 3.04/1 Mar. } \\
1.61 / 28 \text { Nov. }\end{array}$ & $\begin{array}{l}0.48 \\
1.70 \\
\end{array}$ & $\begin{array}{c}0.01 / 2 \text { May } \\
0.39 / 4 \text { Jul. }\end{array}$ & $\begin{array}{c}\text { 1.22/18 Sep. } \\
\text { 3.8/2 May }\end{array}$ \\
\hline $\begin{array}{c}\text { Silicate }(\mu \mathrm{M}) \\
\text { A,B,O,Br } \\
\text { C } \\
\end{array}$ & $\begin{array}{l}27.74 \\
39.14 \\
\end{array}$ & $\begin{array}{l}\text { 11.35/18 Jan. } \\
\text { 27.03/24 Jan. }\end{array}$ & $\begin{array}{l}\text { 94.28/12 Dec. } \\
\text { 58.09/28 Nov. }\end{array}$ & $\begin{array}{l}13.97 \\
31.97 \\
\end{array}$ & $\begin{array}{l}\text { 4.19/2 May } \\
18.3 / 2 M a y\end{array}$ & $\begin{array}{l}\text { 56.43/26 Jul. } \\
\text { 60.45/18 Sep. }\end{array}$ \\
\hline $\begin{array}{c}\text { Chl } a \quad\left(\mu \mathrm{g} \cdot 1^{-1}\right) \\
\mathrm{A}, \mathrm{B}, \mathrm{O}, \mathrm{Br} \\
\mathrm{C}\end{array}$ & $\begin{array}{l}1.18 \\
3.58 \\
\end{array}$ & $\begin{array}{l}\text { 0.34/7 Feb. } \\
0.43 / 24 \text { Jan. }\end{array}$ & $\begin{array}{l}\text { 8.31/1 Mar. } \\
\text { 15.53/7 Nov. }\end{array}$ & $\begin{array}{c}3.8 \\
4.34 \\
\end{array}$ & $\begin{array}{l}\text { 1.03/18 Sep. } \\
1.35 / 30 \text { Oct. }\end{array}$ & $\begin{array}{l}\text { 16.78/2 May } \\
\text { 13.84/2 May }\end{array}$ \\
\hline $\begin{array}{c}\text { Total seston }\left(\mathrm{mg} \cdot \mathrm{l}^{-1}\right) \\
\mathrm{A}, \mathrm{B}, \mathrm{O}, \mathrm{Br} \\
\mathrm{C}\end{array}$ & $\begin{array}{c}44.16 \\
1637.9 \\
\end{array}$ & $\begin{array}{l}\text { 9.54/24 Jan. } \\
\text { 18.31/7 Feb. }\end{array}$ & $\begin{array}{l}\text { 163.34/7 Nov. } \\
\text { 8820.5/1 Mar. }\end{array}$ & $\begin{array}{l}16.24 \\
57.92 \\
\end{array}$ & $\begin{array}{c}\text { 4.8/5 Jun. } \\
\text { 12.38/5 Jun. }\end{array}$ & $\begin{array}{l}\text { 134.6/24 Aug. } \\
\text { 263.5/24 Aug. }\end{array}$ \\
\hline Charente runoff $\left(\mathrm{m}^{3} \cdot \mathrm{s}^{-1}\right)$ & 104.19 & 24.50/16 Nov. & 380/10 Mar. & 29.46 & 9.83/8 Sep. & 71.2/25 Apr. \\
\hline
\end{tabular}


Table S2. Mean, minimum and maximum values of the abiotic and chlorophyll $a$ parameters with date occurrence at Arcachon Bay (B13 and Comprian stations). The seasons were defined based on the results of PCA clustering temporally the sampling stations; winter season from January to the end of April 2005. The rest of the year was considered as the summer season. Runoff data were supplied by DIREN-Aquitaine/HYDRO$906 \mathrm{MEDD} / \mathrm{DE}$ for Leyre River

\begin{tabular}{|c|c|c|c|c|c|c|}
\hline Arcachon & Mean & $\begin{array}{l}\text { Winter } \\
\text { Min/date }\end{array}$ & Max/date & Mean & $\begin{array}{l}\text { Summer } \\
\text { Min/date }\end{array}$ & Max/date \\
\hline $\begin{array}{cc}\text { Water temperature } & \left({ }^{\circ} \mathrm{C}\right) \\
\text { B13 } & \\
\text { Comprian } & \\
\end{array}$ & $\begin{array}{l}10.30 \\
10.01 \\
\end{array}$ & $\begin{array}{l}\text { 7.4/5Mar. } \\
\text { 5.4/5 Mar. }\end{array}$ & $\begin{array}{c}\text { 14.8/29 Apr. } \\
\text { 16.42/29 Apr. }\end{array}$ & $\begin{array}{l}18.04 \\
20.72 \\
\end{array}$ & $\begin{array}{l}\text { 14.27/14 May } \\
16.85 / 14 \text { May }\end{array}$ & $\begin{array}{l}21.07 / 23 \mathrm{Jul} \text {. } \\
22.92 / 16 \mathrm{Jul} \text {. }\end{array}$ \\
\hline $\begin{array}{c}\text { Salinity (PSU) } \\
\text { B13 } \\
\text { Comprian } \\
\end{array}$ & $\begin{array}{l}34.26 \\
31.06 \\
\end{array}$ & $\begin{array}{l}\text { 24.02/29 Apr. } \\
\text { 30.15/10 Feb. }\end{array}$ & $\begin{array}{c}\text { 34.55/9 Apr. } \\
32 / 9 \mathrm{Apr} .\end{array}$ & $\begin{array}{c}34.49 \\
33.5 \\
\end{array}$ & $\begin{array}{l}\text { 32.3/16 Jul. } \\
\text { 31.4/6 May. }\end{array}$ & $\begin{array}{l}\text { 35.4/2 Jul. } \\
\text { 35/30 Aug. }\end{array}$ \\
\hline $\begin{array}{c}\text { Nitrate }(\mu \mathrm{M}) \\
\text { B13 } \\
\text { Comprian }\end{array}$ & $\begin{array}{c}5 \\
8.19\end{array}$ & $\begin{array}{c}0.77 / 29 \text { Apr. } \\
\text { 2/2 Apr. }\end{array}$ & $\begin{array}{l}11.21 / 19 \mathrm{Feb} . \\
15.51 / 31 \mathrm{Jan} .\end{array}$ & $\begin{array}{l}0.27 \\
0.93\end{array}$ & $\begin{array}{l}0.19 / 23 \text { Jul. } \\
0.26 / 16 \text { Jul. }\end{array}$ & $\begin{array}{l}0.48 / 6 \text { Ma. } \\
\text { 4.99/6 May }\end{array}$ \\
\hline $\begin{array}{c}\text { Ammonium }(\mu \mathrm{M}) \\
\text { B13 } \\
\text { Comprian }\end{array}$ & $\begin{array}{l}0.93 \\
1.98\end{array}$ & $\begin{array}{l}\text { 0.12/29 Apr. } \\
0.59 / 12 \mathrm{Mar} \text {. }\end{array}$ & $\begin{array}{l}\text { 4.71/31 Jan. } \\
6.46 / 31 \text { Jan. }\end{array}$ & $\begin{array}{l}0.15 \\
1.15\end{array}$ & $\begin{array}{c}\text { 0.03/14 May } \\
0.42 / 16 \text { Jul. }\end{array}$ & $\begin{array}{l}\text { 0.59/30 Aug. } \\
\text { 2.38/30 Aug. }\end{array}$ \\
\hline $\begin{array}{c}\text { Phosphate }(\mu \mathrm{M}) \\
\text { B13 } \\
\text { Comprian } \\
\end{array}$ & $\begin{array}{l}0.76 \\
0.59 \\
\end{array}$ & $\begin{array}{l}0.37 / 29 \text { Apr. } \\
0.28 / 10 \text { Feb. }\end{array}$ & $\begin{array}{l}\text { 2.34/26 Mar. } \\
\text { 1.8/26 Mar. }\end{array}$ & $\begin{array}{c}0.27 \\
0.4 \\
\end{array}$ & $\begin{array}{l}0.18 / 30 \text { Aug. } \\
0.27 / 9 \text { Jul. }\end{array}$ & $\begin{array}{c}0.36 / 6 \text { May } \\
0.82 / 13 \text { Aug. }\end{array}$ \\
\hline $\begin{array}{c}\text { Silicate }(\mu \mathrm{M}) \\
\text { B13 } \\
\text { Comprian }\end{array}$ & $\begin{array}{c}4.65 \\
13.96\end{array}$ & $\begin{array}{l}0.82 / 9 \mathrm{Apr} \text {. } \\
6.59 / 2 \mathrm{Apr} \text {. }\end{array}$ & $\begin{array}{l}\text { 7.10/23 Jan. } \\
\text { 21.93/31 Jan. }\end{array}$ & $\begin{array}{c}3.6 \\
10.69\end{array}$ & $\begin{array}{l}1.31 / 20 \text { Aug. } \\
5.75 / 30 \text { Aug. }\end{array}$ & $\begin{array}{l}11.11 / 25 \text { Jun. } \\
17.78 / 25 \text { Jun. }\end{array}$ \\
\hline $\begin{array}{c}\text { Chl } a \quad\left(\mu \mathrm{g} . \mathrm{l}^{-1}\right) \\
\text { B13 } \\
\text { Comprian }\end{array}$ & $\begin{array}{l}0.95 \\
1.09 \\
\end{array}$ & $\begin{array}{c}0.44 / 12 \text { Mar. } \\
0.6 / 5 \text { Mar. }\end{array}$ & $\begin{array}{c}1.61 / 2 \mathrm{Apr} . \\
1.9 / 2 \mathrm{Apr} .\end{array}$ & $\begin{array}{l}0.77 \\
1.37 \\
\end{array}$ & $\begin{array}{l}\text { 0/30 Aug. } \\
\text { 0.72/18 Jun. }\end{array}$ & $\begin{array}{c}1.55 / 28 \text { May } \\
2.32 / 4 \text { Jun. }\end{array}$ \\
\hline $\begin{array}{c}\text { Total seston }\left(\mathrm{mg} . \mathrm{l}^{-1}\right) \\
\text { B13 } \\
\text { Comprian } \\
\end{array}$ & $\begin{array}{l}34.64 \\
33.74 \\
\end{array}$ & $\begin{array}{c}\text { 5.59/2 Apr. } \\
6.44 / 19 \text { Mar. }\end{array}$ & $\begin{array}{l}\text { 216.2/23 Jan. } \\
\text { 208.7/23 Jan. }\end{array}$ & $\begin{array}{l}0.765 \\
0.920 \\
\end{array}$ & $\begin{array}{l}\text { 0.470/6 May } \\
0.56 / 30 \text { Aug. }\end{array}$ & $\begin{array}{c}1.15 / 18 \mathrm{Jun} . \\
1.36 / 9 \mathrm{Jul} .\end{array}$ \\
\hline Leyre runoff $\left(\mathrm{m} 3 . \mathrm{s}^{-1}\right)$ & 13.46 & 9.69/26 Mar. & 22.8/27 Apr. & 6.44 & 4.02/25 Aug. & 16.5/1 May \\
\hline
\end{tabular}


Figure 1

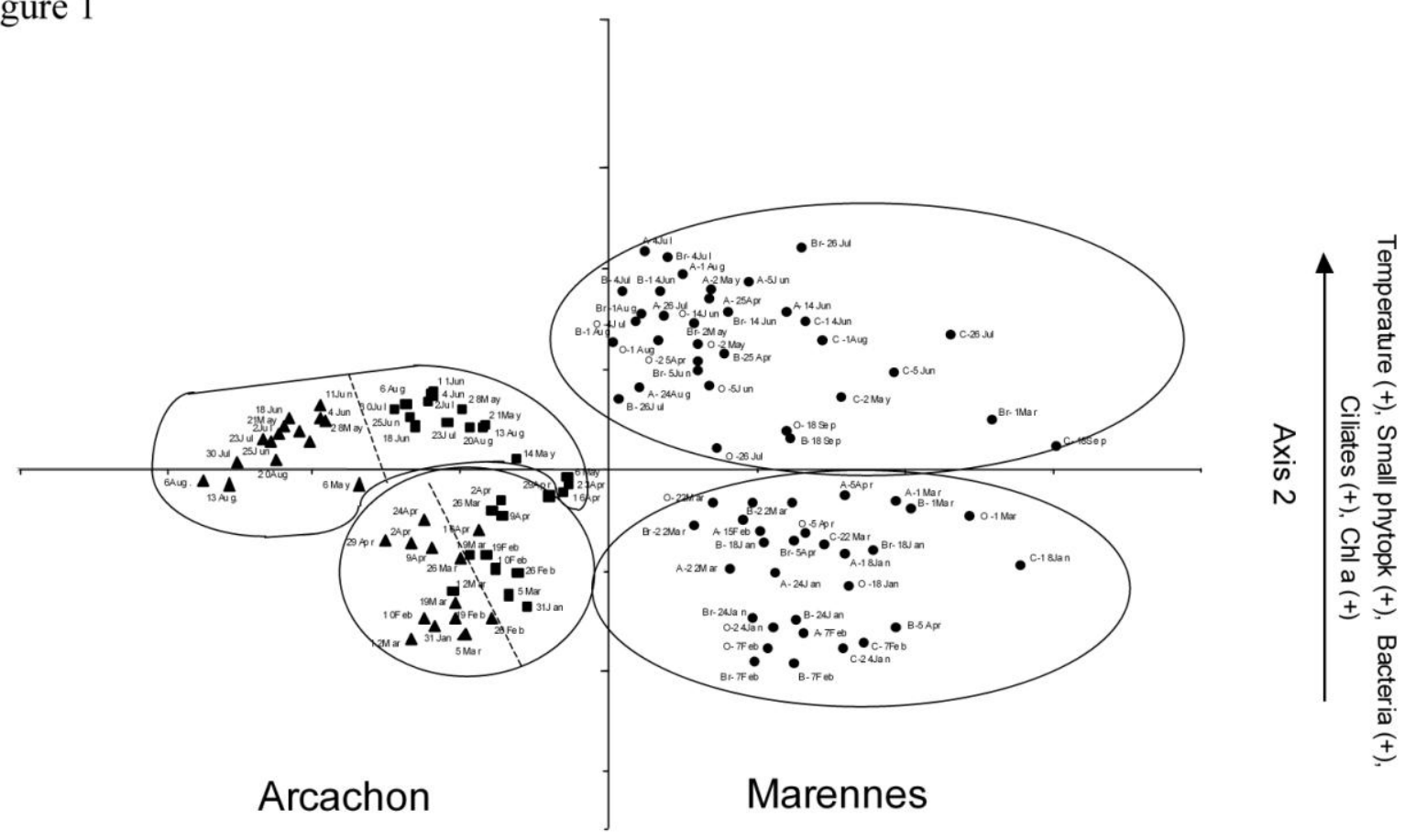

Axis 1

Nutrients (+), Seston Org. (+), Cryptophyceae ( -), Virus (+), Synechococcus

$(-)$, Diatoms (-), Salinity (-)

Fig. 1. Ordination by principal component analysis (PCA) of the basin stations obtained from microbiological, physical and chemical log transformed data in Arcachon (January to September 2005; \ B13, @ Comprian, with sampling date) and Marennes-Oléron Bay (2006; • with sampling stations and date). Arrows parallel to each axis: structuring variables. Ellipses: clusters based on hierarchical ascendant classification analysis (HAC) performed with coordinates of the station plots (straight and dotted lines: first and second discriminant in HAC, respectively). 
A

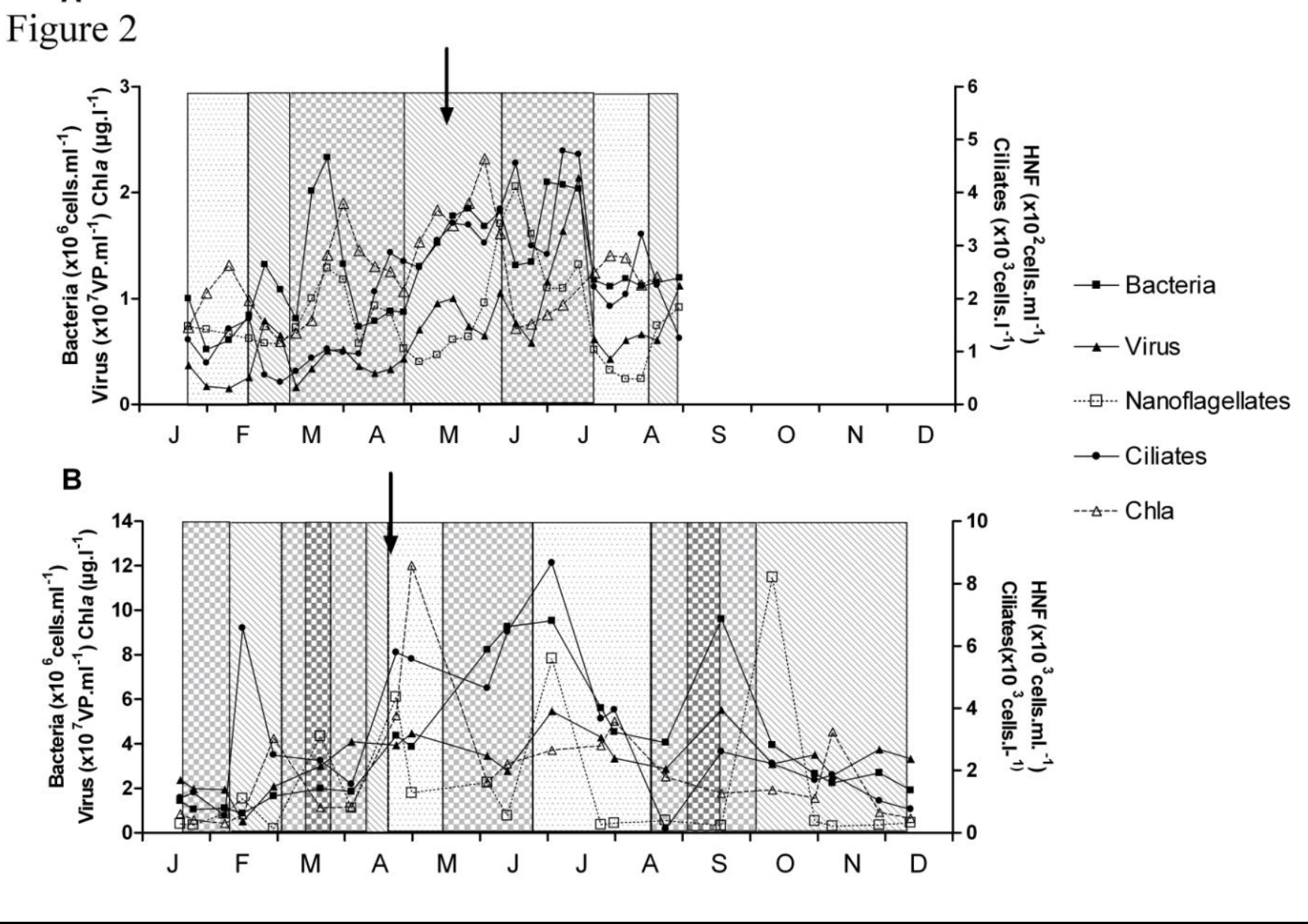

Fig. 2. Temporal dynamics of bacteria ( $\Delta)$, viruses ( $\mathbf{\square})$, nanoflagellates $(\square)$, ciliates (x) abundance and chlorophyll $a(\Delta)$ concentration in the 2 study sites, Arcachon in 2005 (A: Comprian station) and Marennes in 2006 (B: Mean of the 5 stations). The trophic periods are represented by different background patterns: $\quad$ Herbivorous food web; $\$$ Multivorous food web; $\square$ Microbial food web; $\square$ Microbial loop. Arrows indicate the in vitro experiment periods. 
Arcachon
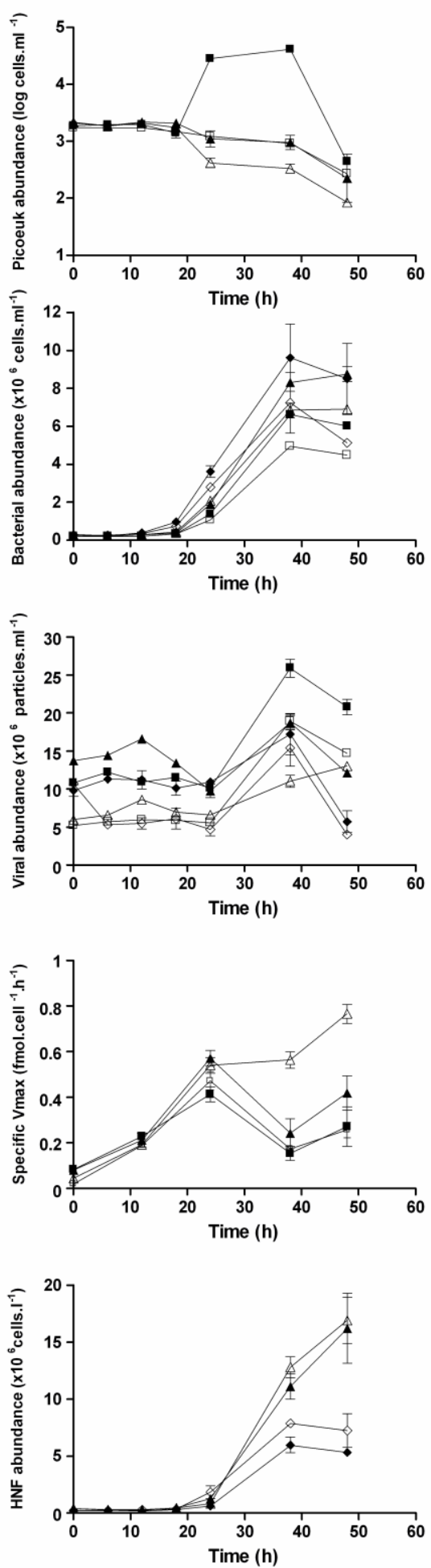

Marennes
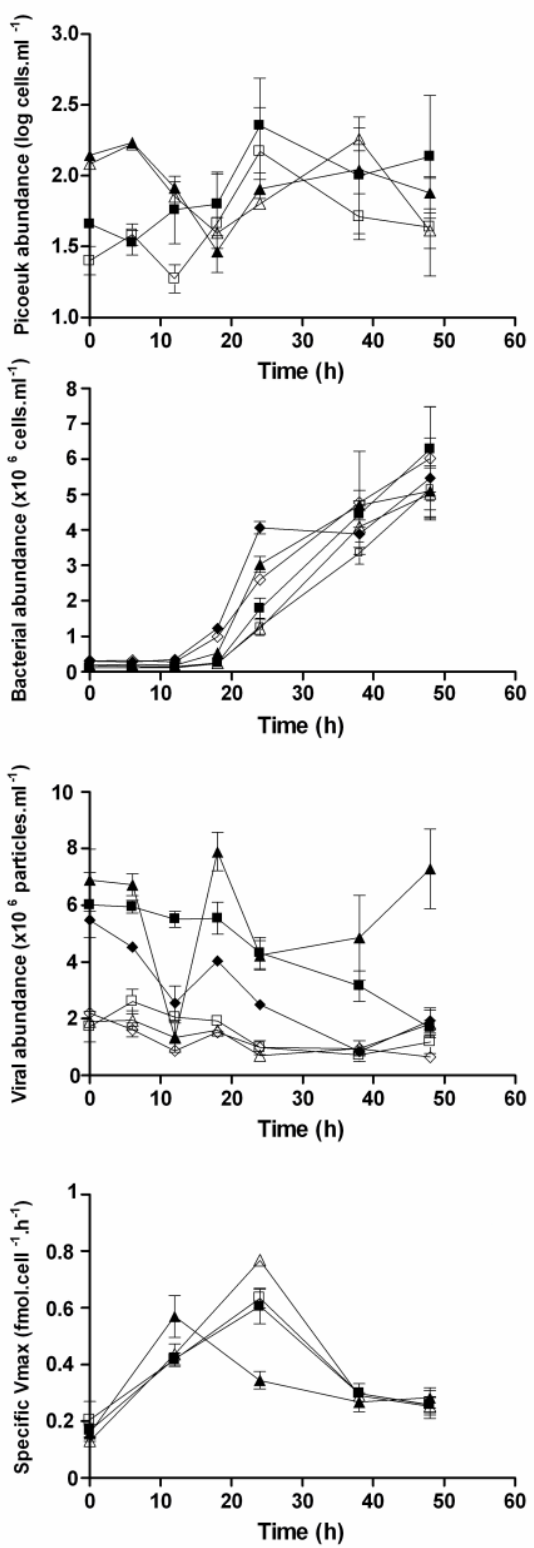

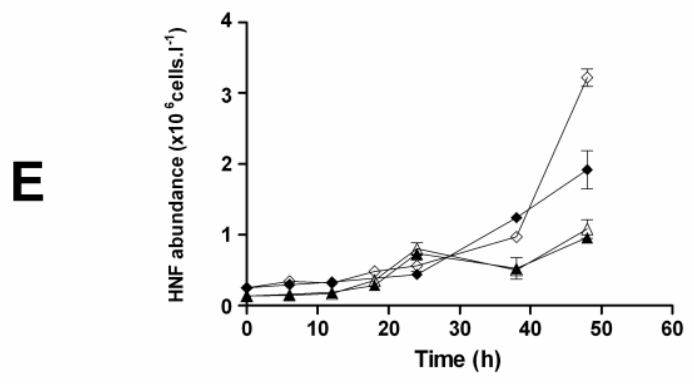

A

B

C

D

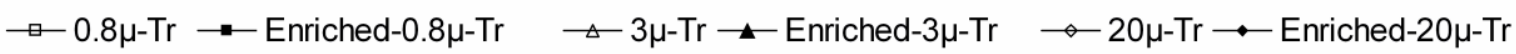

Fig. 3. Time course of the logarithmic abundance of picophytoeukaryotes (A), abundance of bacteria (B), viruses (C), heterotrophic nanoflagellates (HNF) (E) and specific aminopeptidase bacterial activity (D) in Arcachon and Marennes experiments. Means \pm SD of triplicate incubations for each treatment. 
Figure 4

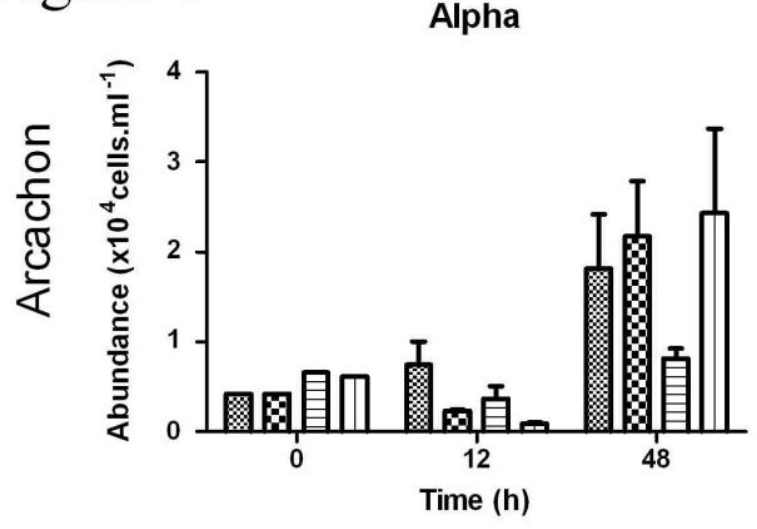

Alpha

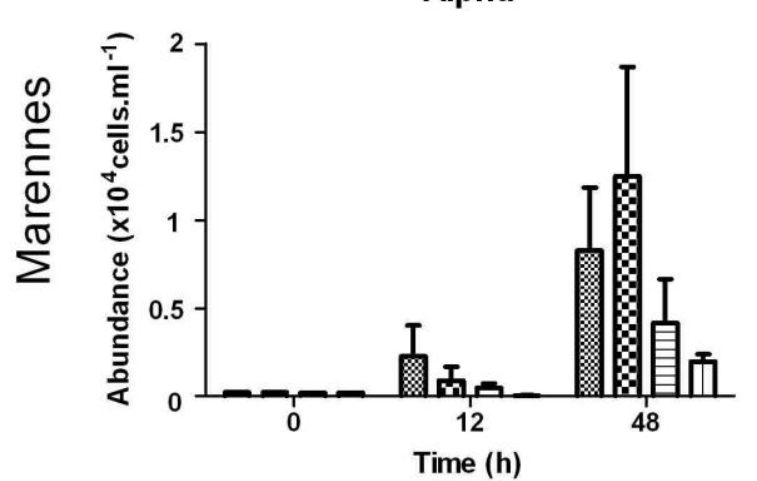

Beta

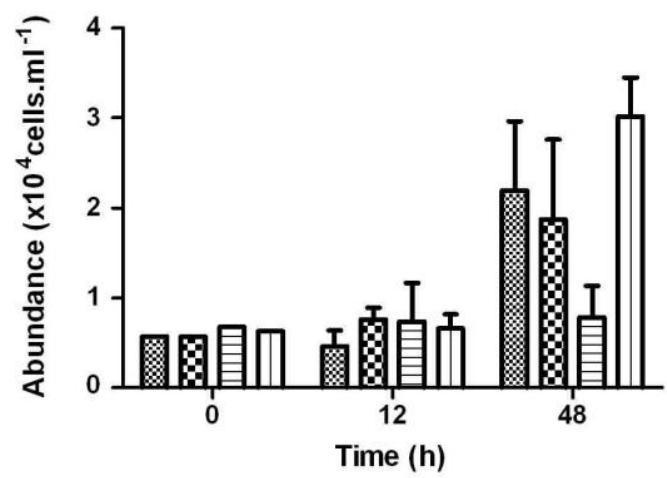

Beta

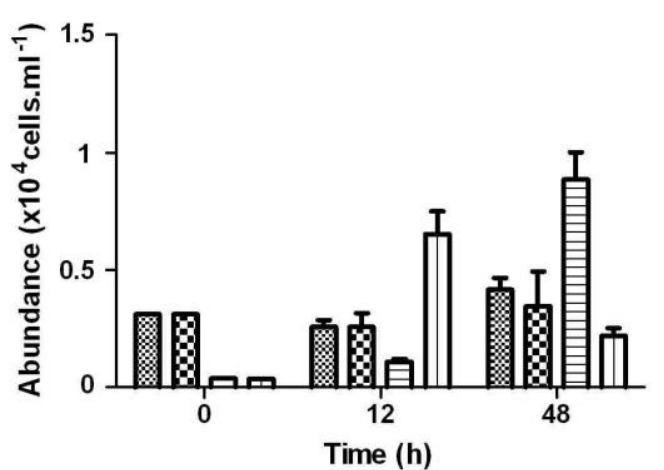

Gamma

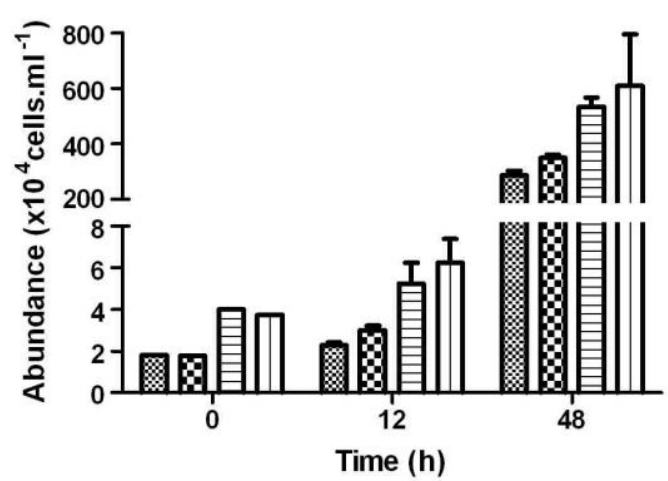

Gamma

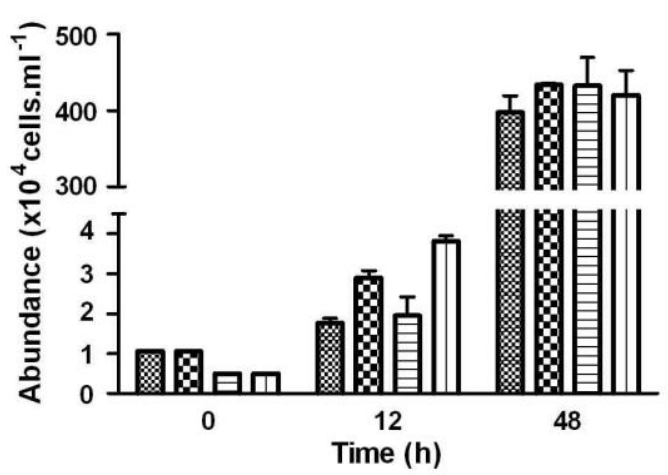

Fig. 4. Bacterial community composition based on FISH analysis: dynamics of Alpha-, Beta- and Gamma-proteobacteria in different treatments of Arcarchon and Marennes experiments. Gamma abundance at T48 is read on the right axis of each graph. Means \pm SE of triplicate incubations for each 940 treatment. 


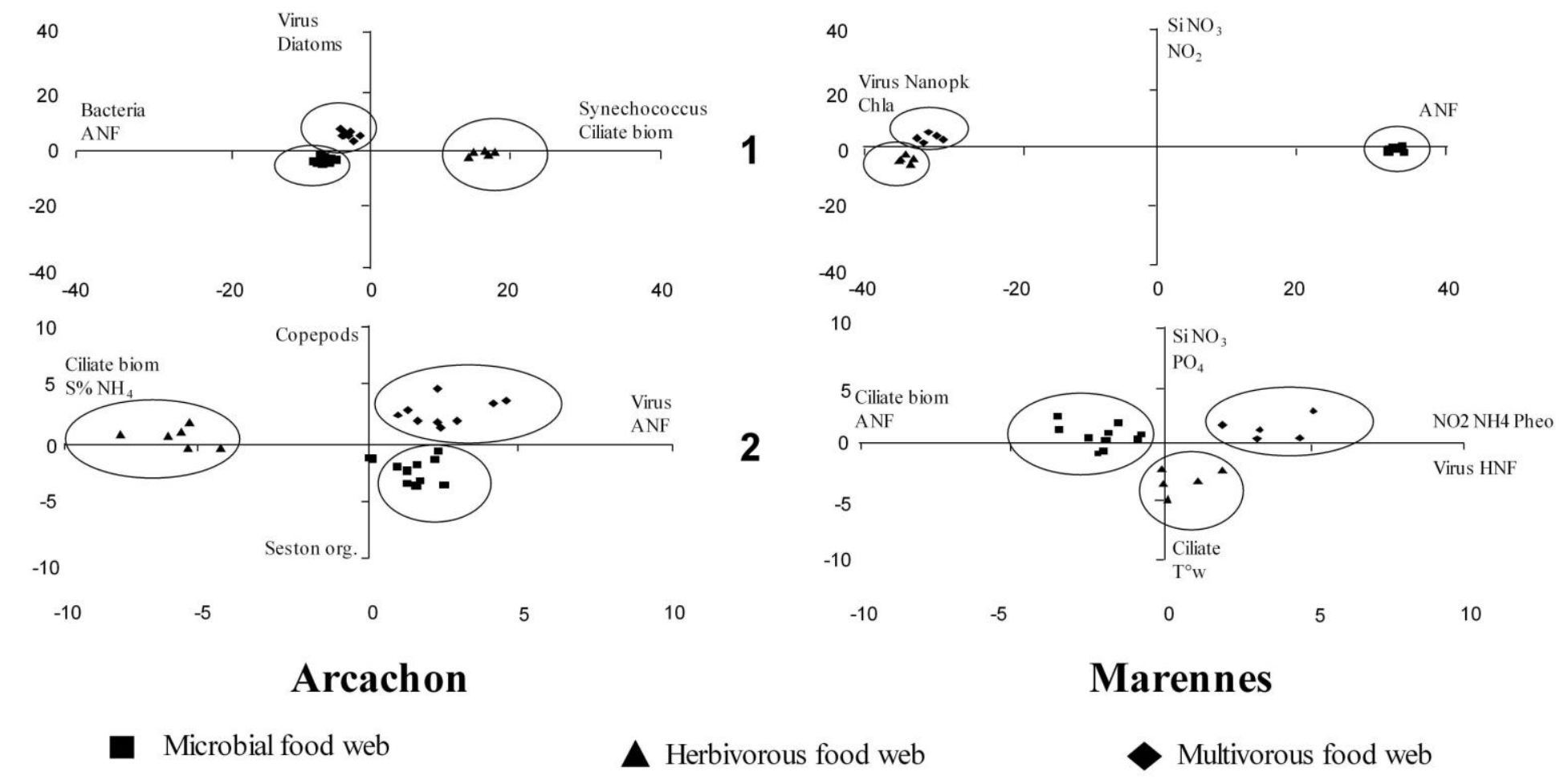

Fig. S1. Ordination by factorial discriminant analaysis (FDA) of samples from Arcachon (Comprian station) and Marennes (mean of the 5 stations). FDA generated from microbiological, physical and chemical data (log transformed) and using an empirical trophic model as a criterion variable ( $\mathbf{m}, \mathbf{\Lambda}$, ): (1) with all the parameters and (2) excluding the principal factors used for the definition of trophic groups (large and small phytoplankton and bacteria abundance). Samples are clustered according to the trophic pattern. The microbial loop class was combined with the microbial food web class because few samples representing the former were found in Marennes and it was absent in Arcachon. Independent variables: salinity, water temperature, silicate, phosphate, ammonium, nitrate, nitrite, organic seston, pheopigment and chlorophyll $a$ concentrations, abundance of viruses, bacteria, autotrophic nanoflagellates, heterotrophic nanoflagellates, ciliates, picoplankton, nanoplankton, Synechococcus, diatoms and Dinophyceae, biomass of ciliates and bacteria, copepods. Structuring variables are annotated along each axis: S\%: salinity, ANF: Autotrophic nanoflagellates, Ciliate biom: Biomass of ciliates, Chla: Chlorophyll $a$ concentration, Picopk: Picoplankton abundance, Nanopk: Nanoplankton abundance, Si: Silicate, $\mathrm{NO}_{2}$ : Nitrite, $\mathrm{NO}_{3}$ : Nitrate, $\mathrm{NH}_{4}$ : Ammonium, $\mathrm{PO}_{4}$ : Phosphate, Seston org.: Organic seston, Pheo: Pheopigment concentration, $\mathrm{T}^{\circ} \mathrm{w}$ : water temperature. 


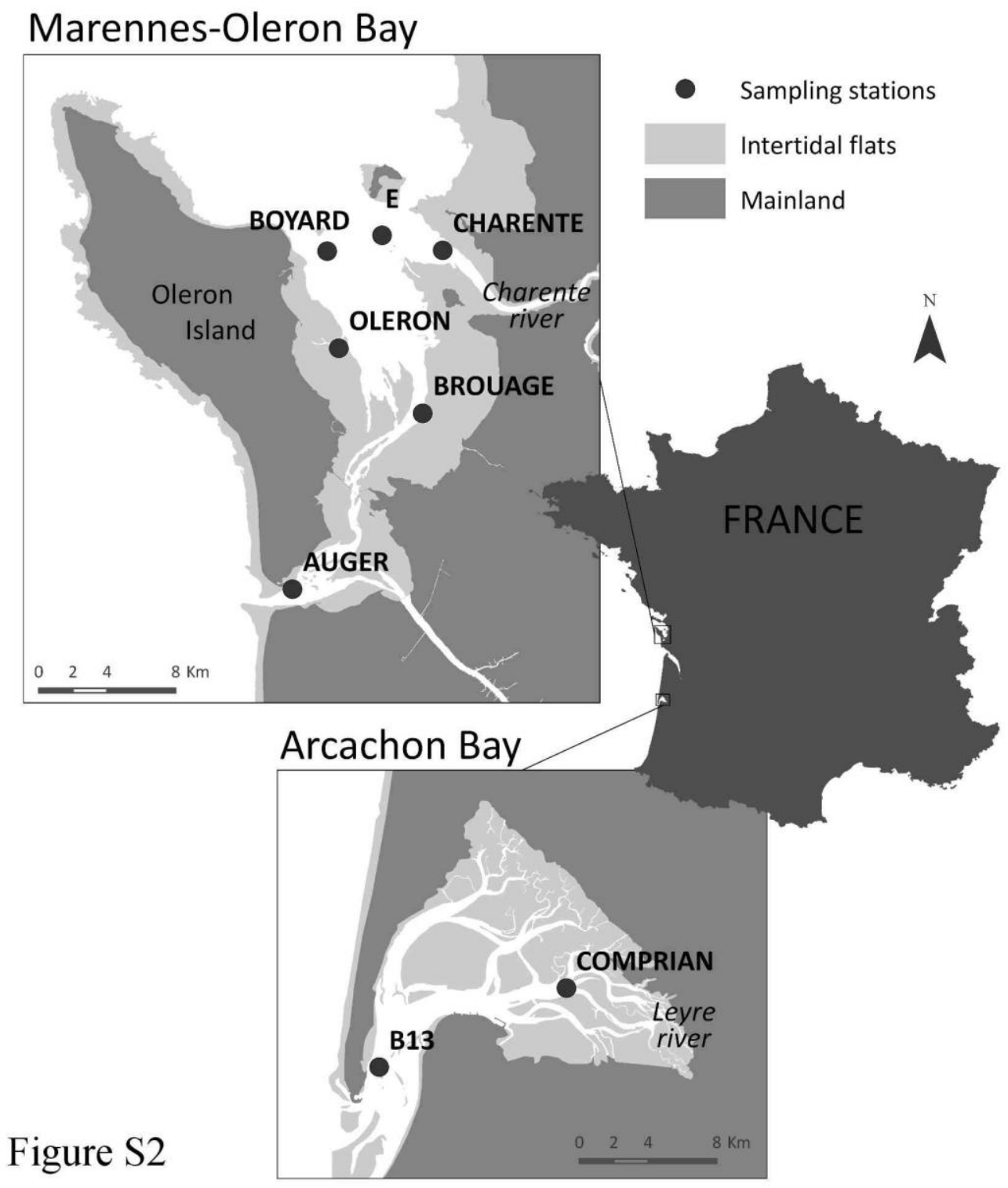

Fig. S2. Map of the 2 study sites, Marennes-Oléron Bay and Arcachon Bay, Atlantic coast, France, showing the locations of the in situ sampling stations: Marennes Bay, stations Boyard 960 $\left(45^{\circ} 58^{\prime} 43.73^{\prime} \mathrm{N}, \quad 1^{\circ} 12^{\prime} 30.47^{\prime}, \mathrm{W}\right), \quad$ Charente $\quad\left(45^{\circ} 58^{\prime} 54.94^{\prime}{ }^{\prime} \mathrm{N}, \quad 1^{\circ} 07^{\prime} 17.28^{\prime \prime} \mathrm{W}\right)$, Oléron $\left(45^{\circ} 55^{\prime} 41.47^{\prime}, \mathrm{N}, \quad 1^{\circ} 11^{\prime} 47.1^{\prime} \mathrm{W}\right), \quad$ Brouage $\left.\quad{ }^{\circ} 53^{\prime} 45.58^{\prime}{ }^{\prime} \mathrm{N}, 1^{\circ} 07^{\prime} 52.15^{\prime}, \mathrm{W}\right)$ and Auger

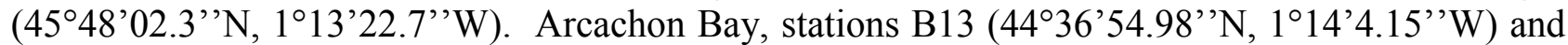
Comprian $\left(44^{\circ} 40^{\prime} 22.8^{\prime} \mathrm{N}, 1^{\circ} 04^{\prime} 38.1^{\prime \prime} \mathrm{W}\right)$. Location of the sampling stations for in vitro 964 experiments: in Marennes Bay, station E (45 59'18.7' 'N, $1^{\circ} 10^{\prime} 0.69^{\prime}$ 'W), in Arcachon Bay, station 965 